\title{
A origem intelectual das orações em tupi de André Thevet e Yves d'Evreux (séculos XVI-XVII): algumas hipóteses ${ }^{1}$
}

Maria Cândida Drumond Mendes Barros
Museu Emílio Goeldi

\section{Abstract}

The aim of this study is to identify the intellectual origins of the prayers in Tupi, published by the French clerics André Thevel and Yves d'Evreux in the XVI and XVII centuries. 


\section{INTRODUÇÃO}

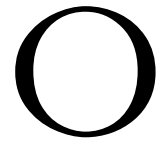

objetivo da pesquisa é identificar a origem intelectual das orações em tupi publicadas pelos religiosos franceses André Thevet e Yves d'Evreux nos séculos XVI e XVII. Os dois autores publicaram as orações inseridas em um gênero de literatura popular na França naquele período, que era o relato de viagem. André Thevet incluiu em seu livro Cosmographie Universelle em 1575 e no manuscrito Le Grand Insulaire et Pilotage d'Andre Thevet Angoumoisin, Cosmographe du Roy. Dans lequel sont contenus plusieurs plants d'isles habitées et deshabitées, et description d'icelles (1586-1587) versões em tupi da "Oraison Dominicale en Sauvage" (Pai Nosso), "Salutation Angelique" (Ave Maria) e "Le Simbole des Apostres" (Credo). Yves d'Evreux, em seu livro Suitte de l'Histoire des choses mémorables advenues en Maragnan, es annés 1613 et 1614 (impresso em 1615), publicou em tupi: "Oraison Dominicale", "La Salution Angelique", "Oraison à la Vierge", "Le Symbole des Apostres", "Les dix commandemens de Dieu, "Sommaire des Commandemens de Dieu", "Les commandemens de la Saincte Eglise"e "Les Sept Sacremens". As orações em comum nos dois autores - como o Pai Nosso - não representam a mesma versão, indicador, portanto, de terem tido procedências distintas.

Ambos publicaram textos em tupi antes dos jesuítas portugueses, que, desde 1549, já mantinham uma política de evangelização nessa língua no Brasil. Thevet publicou textos em tupi, antes mesmo da gramática de Anchieta (1595), primeira obra que os jesuítas imprimiram sobre o tupi. Apenas em 1618, foi publicado o catecismo tupi do jesuíta Antônio Araújo.

A pesquisa sobre as orações em tupi publicadas por Thevet e d'Evreux segue uma abordagem de historiografia lingüistica na qual 
estão em questão dois gêneros literários: o catecismo e o relato de viagem. Em particular, interessará acompanhar a passagem das orações do catecismo para o relato de viagem. O exercício de identificação da origem intelectual das orações em tupi publicadas por Thevet e d'Evreux seguirá os seguintes passos:

a) contextualizar Thevet e d'Evreux nos projetos da França Antártica e França Equinocial. Interessará também recolher os dados sobre a estadia de Thevet e d'Evreux na costa do Brasil, as indicações sobre o domínio que eles tiveram do tupi , as menções às orações nessa língua nas obras em análise e às formas de uso que esses textos tiveram para seus autores;

b) correlacionar os textos dos religiosos franceses com o que foi publicado sobre a língua tupi nos livros de viagem na França;

c) localizar os textos em tupi dos dois franceses na história dos catecismos jesuíticos. Para esse tópico, nos basearemos nas cartas jesuíticas desse período;

d) comparar o Pai Nosso em Thevet e d'Evreux com as versões jesuíticas;

e) por fim, discutir algumas hipóteses sobre a origem desses textos cristãos em tupi, tomando em consideração os resultados dos tópicos anteriores.

A origem intelectual será tratada como autoria institucional e não individual. O interesse por esses dois textos tupis está relacionado ao projeto de pesquisa "Catecismo em línguas indígenas brasileiras: história de sua formação e do seu uso (séculos XVI-XVIII)”. No presente trabalho, a proposta é inserir e contextualizar, na história dos textos religiosos jesuíticos em tupi, aqueles publicados pelos dois religiosos franceses.

\section{ANDRÉ THEVET NO CONTEXTO DA FRANÇA ANTÁRTICA (SÉCULO XVI)}

André Thevet (1516-1592) veio ao Brasil dentro do projeto da França Antártica, que estabeleceu uma colônia no Rio de Janeiro. 
Dessa experiência foram publicadas na França algumas crônicas: a do protestante Jean de Lery (Histoire d'un voyage faict en la terre du Brésil/1578) e a de André de Thevet (Singularitez de la France Antarctique, autrement nommée Amerique: et de plusieurs Terres et Isles decouvertes de nostre temps/1557). Thevet escreveu outras obras em que aborda a experiência no Brasil: La Cosmographie Universelle em 1575 e, por fim, o manuscrito Le Grand Insulaire et Pilotage d'Andre Thevet Angoumoisin, Cosmographe du Roy. Dans lequel sont contenus plusiers plants d'isles habitées et deshabitées, et description d'icelles (1586-1587). Os dois últimos são os que contêm as orações em tupi.

As orações não teriam sido usadas por Thevet na evangelização dos índios. Sua função na viagem ao Brasil foi de cosmógrafo e não de missionário, ao contrário da presença de Lery e seus companheiros (REVERDIN, 1957).

A permanência de André Thevet no Rio foi de dez semanas, entre meados de novembro de 1555 e o fim de janeiro de 1556. Ele aportou no Rio de Janeiro acompanhando Villegaignon. Um ano depois do seu retorno à França, Thevet publicou o relato de sua viagem em Singularitez. As obras de Thevet sofreram denúncias de que teriam tido co-autores como Mathurin Héret, Filber Betin e F. de Belleforest (LESTRINGANT, 1990). Porém as acusações de plágio não entrarão na discussão a respeito da origem intelectual das orações em tupi, pois a participação dos três nos livros de Thevet foi em relação às inclusões de referências a gregos e romanos, típicas nesse tipo de obra de caráter enciclopédico, e, para a qual, Thevet não tinha formação erudita. Nenhum dos três nomes, que requisitaram autoria nos livros de Thevet, estiveram no Brasil.

Singularitez faz parte do gênero dos relatos de viagem com menções às curiosidades encontradas no Novo Mundo. Em vários momentos, o autor se dirige ao leitor para afirmar que a veracidade de sua informação se deve a tê-las visto e vivenciado. As duas outras obras Cosmographie Universelle e Le Grand Insulaire acrescentam outro elemento a essa experiência no Brasil, que foi a polêmica entre 
Thevet e Lery. Nessas duas obras de Thevet, há uma defesa de Villegaignon e uma crítica a Lery e incluem um debate de caráter religioso que não esteve presente na primeira obra. As orações em tupi surgem nas obras de Thevet escritas durante a polêmica entre ele e Jean de Lery.

Em termos de dados sobre a língua tupi, as três obras de Thevet são heterogêneas: enquanto em Singularitez há pouca presença de trechos em tupi, Cosmographie e Le Grand Insulaire apresentam mais dados inseridos ao longo do texto. Uma das possibilidades para esse incremento de dados do tupi, entre o que foi publicado em 1557 e as obras posteriores, pode ter sido o dicionário tupi, obtido por Thevet em 1567, como menciona em Le Grand Insulaire (THEVET, 1586, p. 252). Outra hipótese para aumento de dados lingüísticos em sua obra foi a colaboração de intérpretes franceses, quando retornaram para a Europa, depois do fracasso do projeto colonial francês.

Em Cosmographie, reeditado por Lussagnet em 1953, Thevet declara ser o tradutor das orações tupis, ao mencionar as dificuldades que teve para fazê-lo: "Il ya a quelques noms propres, lesquels je n'ay peu traduire en leur langue" (LUSSAGNET, 1953, p. 95). Se for considerado o pouco tempo que Thevet permaneceu no Brasil (dez semanas), e ainda que nessa temporada esteve doente, reduz a possibilidade de ter sido ele o autor das traduções. Não há nenhum indício de que Thevet tivesse domínio do tupi. Ao contrário, ele parece estar sempre acompanhado pelos intérpretes, os quais às vezes ele chama de "pilotos" franceses (THEVET, 1944, p. 33), que são fonte de suas observações cosmográficas. Também "Don Petro", um prisioneiro português que falava bem o tupi, lhe serviu de intérprete para recolher as informações sobre elementos da natureza. Em outro momento, THEVET (1944, p. 76) menciona a ajuda de um truchement francês que sabia bem a língua depois de ter estado dez anos no Brasil.

Segundo Jurn Philipson (apud LUSSAGNET, 1953, p. 94), Thevet teria retranscrito orações jesuíticas em uso entre os maracaios ou temiminos, recolhidas através de um índio cristianizado, escravo de um tamoio, ou teria obtido manuscritos portugueses. 


\section{YVES D'EVREUX NO CONTEXTO DA FRANÇA EQUINOCIAL (SÉCULO XVII)}

O capuchinho Yves d'Evreux (1577-1632?) participou da experiência colonial da França Equinocial (1612 e 1616) na região do Maranhão, junto com outros três padres (d'Abbeville, Arsênio e Ambrosio) do convento de Saint-Honoré. A ordem francesa, até então, não tinha tido nenhuma outra experiência de evangelização no Novo Mundo.

Várias pequenas publicações foram feitas pelos missionários franceses no Maranhão (d'Abbeville 1613/1614, Arsène 1612), porém as duas principais obras sobre os tupinambás e as atividades dos capuchinhos no Maranhão foram os livros de d'Abbeville (1614), publicados depois de quatro meses na região, Histoire de la mission des pères capucins en l'isle de Maragnan et terres circonvoisines, où est traicté des singularitez admirables et des moeurs merveilleuses des Indièns habitans de ce pays, e de d'Evreux, Suitte de l'Histoire des choses mémorables advenues en Maragnan, es annés 1613 et 1614 (1615). O livro de d'Evreux foi publicado no seu retorno a Paris, depois de um ano no Maranhão, proposto como continuação à obra de d'Abbeville.

O livro de d'Evreux não teve nenhuma difusão, porque foi destruído na oficina do impressor depois de publicado, por motivos políticos. Como o rei francês havia se casado com a infanta da Espanha, tornou-se desinteressante o plano de montar uma colônia francesa em terras da família real espanhola, no período filipino.

$\mathrm{Na}$ crônica de d'Abbeville sobre os quatro primeiros meses dos capuchinhos no Maranhão, há menção ao uso do mesmo repertório de orações publicadas posteriormente por d'Evreux. Para um índio ser batizado pelos capuchinhos era exigido que ele tivesse domínio dessas orações, como relata D'EVREUX (1864, p. 243): "apprendroit diligemment toute la Doctrine Chrestienne, laquelle nous demandions aux Catecumenes avant que de les baptiser"

Os missionários franceses não afirmam que tivessem sido os autores da tradução das orações. Não conta também como chegaram 
a elas. Uma das hipóteses levantadas por CLASTRES (1985) sobre a autoria das orações é que ele teria "retranscrito", para uso dos franceses, textos de outros viajantes. Outra possibilidade é de que um escravo de d'Evreux, cristianizado pelos portugueses, teria sido o responsável de passar o texto jesuítico português para o domínio da evangelização francesa.

Os dois capuchinhos não indicavam terem fluência no tupi. Tanto d'Evreux como d'Abbeville usam intérpretes em suas pregações. Este último indica: "Quelles sont ces choses, disaient-ils, que les pères nous font entendre par leurs truchement?" (D'EVREUX, 1864, p. 205)

Entre os intérpretes usados pelos missionários franceses, um dos poucos referidos por nome foi David Migan. Ele tinha uma posição importante na estrutura colonial francesa montada no Maranhão e foi quem acompanhou um grupo de tubinambás numa viagem à França em 1613, junto com d'Abbeville. A presença de Migan nessa viagem deve ser o motivo pelo qual o livro de d'Abbeville dispõe de mais trechos de discursos em tupi a partir dos capítulos que narram a estadia dos tupinambás na França.

Afora Migan, os demais intérpretes na obra de d'Evreux ou d'Abbeville são pessoas anônimas.

\section{O TRUCHEMENT NORMANDO COMO INTÉRPRETE TUPI DA COLONIZAÇÃO FRANCESA}

As duas experiências de colonização francesa no Brasil foram precedidas pela figura do truchement, adulto ou adolescente francês deixado no litoral com a função de organizar o escambo do pau brasil e de servir de intérprete. Além do pau brasil, havia um tráfico baseado no exotismo do Novo Mundo que incluía o comércio de aves, penas, curiosidades em geral e freqüentemente também índios. O escambo estava sustentado por viagens organizadas por casas normandas de navegação, como a Angos no início do século XVI (FRANCO, 1976, p. 40). Os franceses são mencionados em vários pontos da costa: Santa Catarina (Gonneville em 1504), Bahia de Todos os Santos, Cabo Frio e Rio de Janeiro (THEVET, 1944, p. 144) 
e Maranhão (D’ABBEVILLE, 1945). Anchieta relata abaixo a presença francesa pela costa:

"Os franceses não desistiram de comercio do Brasil, e o principal foi no Cabo Frio e Rio de Janeiro, terra dos tamoyos, os quaes sendo dantes muito amigos dos portugueses, se levantaram contra elles por grandes aggravos e injustiças que lhes fizeram, e receberam os franceses, dos quaes nenhum aggravo receberam e iam e vinham, e carregavam suas naus de pau brasil, pimenta, passaros, bugios e outras coisas da terra, e davam roupa e todo gênero de armas aos índios e os ajudavam contra os portuguesses, e deixavam moços na terra que apprendessem a língua dos índios, e homens que fizessem transportar as mercadorias para quando viessem as naus." (ANCHIETA, 1584 apud Estevão Pinto em THEVET, 1944, p. 144)

A sobrevivência deles estava amparada na estrutura social indígena, ao estabelecerem relações de parentesco através de casamentos com as mulheres indígenas. O sistema do escambo organizado através de relações de aliança dos truchements com os índios era adequado aos franceses que não tinham uma presença militar na região. A eficiência desse sistema pode ser medida pelo longo tempo que os portugueses no Brasil e os espanhóis na Flórida levaram para acabar com esse comércio (LESTRINGANT, 1992). Para dar um exemplo da longevidade dessa relação basta apontar a quase meia década que os franceses estiveram no Maranhão (PIANZOLA, 1991, p. 65). Em contrapartida, foram fugazes as experiências de montar colônias no Rio ou no Maranhão. A França Antártica durou 5 anos (1555 a 1560) e a França Equinocial, 4 anos (1612 a 1616).

Thevet e d'Evreux tiveram auxílio dos truchements para escreverem seus livros com informações sobre os tupinambás. Em sua maioria, os intérpretes permaneceram anônimos nos relatos e eram, quando referidos nos textos, reduzidos a sua função. Algumas das informações esparsas sobre a origem e situação social dos truchements são:

a) origem normanda:

Como a ocupação da costa do Brasil pelos franceses se deu pelos portos da Normandia (Ruão e Dieppe), os truchements ficaram 
identificados como normandos. Em um léxico do século XVI, a palavra truchement eqüivalia a normando (NAVET, 1995, p. 44).

a) "índios brancos" (NAVET, 1995, p. 45):

Uma característica dos franceses na costa do Brasil foi a de estarem integrados à estrutura social indígena, como os descreve Anchieta:

"Vivem [os franceses ] conforme aos índios, comendo, bebendo, bailando e cantando com eles: pintam-se com suas tintas pretas e vermelhas, adornando-se com as penas dos pássaros, andando nus às vezes, só com uns calções, e finalmente matando contrários, segundo o rito dos mesmos índios, e tomando nomes novos como eles, de maneira que não lhes falta mais que comer carne humana, que no mais sua vida é corruptíssima." (CRULS, 1949, p. 40)

A integração dos franceses à estrutura social dos tubinambás foi a base inicial de sustentação das duas experiências coloniais francesas, porém essa interação deixou de ser aceita no momento em que se estabelecia uma administração colonial francesa no Brasil. Jean de Lery, por exemplo, considerava como empecilho para o estabelecimento de uma sociedade cristã na colônia a integração dos franceses ao modo de vida dos índios.

\footnotetext{
"A mon grand regret, je suis constraint de réciter ici que quelques truchements de Normandie que avaient demeuré huit ou neuf ans en ce pays là, pour s'accommoder à eux, menant une vie d'athéistes, ne se polluaient pas seulement en toutes sortes de paillardises et vilenies parmi les femmes et les filles (....), mais aussi, surpassant les sauvages en inhumanité, j'en ai ouï qui se vantaient d'avoir tué et mangé des prisonniers." (LERY apud NAVET, 1995, p. 46)
}

A relação dos truchements com os cronistas e com os representantes coloniais não foi sempre de fidelidade e subordinação. Ao viverem entre duas culturas, acabavam por não pertencer mais a nenhuma delas (MEUNIER, 1999). Lery conta do medo que teve ao ter sido abandonado pelo truchement durante a noite em uma aldeia em meio a cerimônias de canibalismo: 
"Je soupçonnai tout aussitôt que le truchement de propos délibéré m'ayant trahi, m'avait abandonné et livré entre les mains de ces barbares, si j'eusse vu quelque ouverture pour pouvoir sortir et m'enfuir de là, je ne m'y fusse pas feint." (LERY apud NAVET, 1995, p. 46)

A dificuldade de ter intérpretes confiáveis para o projeto religioso que se propunha estabelecer no Brasil era mencionada por um protestante do grupo de Lery. A saída de Villegaignon foi procurar estabelecer seus próprios intérpretes trazendo cinco adolescentes para ocuparem a função.

"Nous n'avons pas d'interprètes qui soient fidèles au Seigneur... Il nous faut donc, en cette entreprise, procéder par étapes, et attendre patiemment qu'aient grandi les enfants que, par l'entremise de Villegagnon, Dieu a confiés aux Sauvages de ce pays pour qu'ils soient élevés parmi eux et apprennent à distinguer leur language naturelle." (RICHIER, 1556 apud REVERDIN, 1957, p. 54).

A proibição do casamento interétnico entre normandos e indígenas foi uma das primeiras medidas de ambas experiências coloniais francesas no Brasil. O receio era de que o estilo de vida levado pelos truchements fosse adotado pelos demais membros da colônia, entre eles os cerca de 300 franceses trazidos por Villegaignon (LESTRINGANT, 1992, p. 328)

"O Senhor de Villegaignon prohibiu, logo ao chegar, os ajuntamentos entre franceses e selvagens, sob pena de morte, uma vez que se tratava de coisa indigna de christãos." (THEVET, 1944, p. 255)

A interdição de Villegaignon às relações entre os truchements e as mulheres tupinambás provocou uma rebelião dos primeiros, os quais, em número de 25 desertaram. A revolta tinha surgido a partir de um intérprete normando que não aceitou as restrições de viver com uma índia.

"Cet individu entretenait avec une fille sauvage un commerce tout autre que de futaines et de petits couteaux. Depuis sept ans, il vivait, 
comme tous les autres truchements, en la plus grande abomination et vie épicurienne qu'il possible de raconter, sans Dieu, sans Foy, ni Loy." (NICOLAS BARRE apud NAVET, 1995, p. 47).

Os truchements tiveram importância central na difusão de dados sobre os tupinambás na França nos séculos XVI e XVII. A presença deles como difusores de informações sobre os tupinambás pode ser encontrada na menção de Montaigne (1533-1592) de que ele teve um servo que havia vivido no Brasil e que lhe forneceu dados para o ensaio Cannibales, onde ele descreve alguns costumes dos tubinambás: "un homme qui avoit demeuré diz ou douze ans en cet autre monde qui a esté decouvert en nostre siecle, en l'endroit ou Villegaignon print terre, qu'il surnomma la France Antartique" (MONTAIGNE apud NAVET, 1995, p. 47).

Com o fracasso da França Antártica, os truchements teriam regressado à França e permitido uma maior difusão dos dados sobre os grupos na costa do Brasil. Uma hipótese é de que o retorno desse grupo à França teria permitido a Thevet aumentar os dados etnográficos e lingüísticos entre Singularitez (1557) e Cosmographie (1575).

\subsection{Embaixadores tubinambás na Europa}

Como contrapartida aos franceses deixados ao longo da costa, alguns índios foram para a Europa a título de reféns. Alguns chegaram à França como embaixadores, quando havia interesse de envolver os reis na montagem de uma colônia francesa no Novo Mundo. Os embaixadores tupinambás deveriam prometer vassalagem aos reis da França, seguida do batismo deles pela família real, como ocorreu com os índios levados por d'Abbeville. Uma das primeiras vindas de embaixadores foi em Ruão, em 1509, com a chegada de sete índios em um navio da Angos com um desfile pela cidade (FRANCO, 1976, p. 40).

Grande parte dos índios chegavam à França como escravos. Uma diferença entre os franceses e os portugueses no tráfico de índios para a Europa foi a preferência dos portugueses pelas mulheres, ao contrário dos franceses que levavam homens (FRANCO, 1976, p. 41). 
Poucos índios não tiveram o destino de escravos. Um deles foi um tabajara que foi para a França ainda criança e voltou adulto casado, mas foi morto pelos tamoios, inimigos do seu grupo (THEVET, 1944, p. 51). D'Evreux fala do índio Grande Raio que havia passado um ano na França, onde aprendera francês e depois voltara para sua aldeia. Outro caso é de Yapoco, ${ }^{2}$ que teve algumas atribulações entre o ir e vir entre o Velho e Novo Mundo. O viajante francês Mocquet menciona tê-lo visto a caminho da França, porém, durante a viagem, o navio foi interceptado pelos ingleses e o índio foi levado para Londres. De lá, Yapoco partiu para a França, à procura de La Ravardière, principal autoridade francesa na costa do Brasil, mas não o encontrou, por estar naquele momento no Brasil. A esposa de La Ravardière fez de Yapoco um criado de sua casa, o que o fez fugir em busca da proteção de Mocquet. No final, o índio acabou sendo obrigado a voltar para a casa de La Ravardière, e Mocquet não teve mais notícias dele (MOCQUET, 1617).

Por fim, o mais antigo relato de índios na França é o de Gonneville em 1504, que levou Esomeriq, então com 15 anos, com promessa de logo voltar (PERRONE-MOISES, 1992). Esomeriq acabou casando com a filha de Gonneville e passou a se chamar Binot Paulmier de Gonneville (FRANCO, 1976, p. 39). Um dos seus descendentes no século XVII, um religioso, se identificava, nos seus livros, como um padre indígena (FRANCO, 1976, p. 39).

\section{OS TUBINAMBÁS COMO TEMA DOS LIVROS DE VIAGEM}

Os tubinambás foram importantes como tema de obras literárias e encenações teatrais na França nos séculos XVI e XVII, com repercussões posteriores na criação da imagem do bom selvagem na obra de Rousseau (FRANCO, 1976). A difusão do tema sobre os índios do Novo Mundo no mundo intelectual francês se dava a partir dos portos da Normandia, como parte do comércio do pau brasil.

Uma das encenações teatrais sobre esse grupo ficou registrada em um folheto publicado no século XVI (DENIS, 1944), no qual se 
relatam as atividades organizadas em Ruão em 1550 pelas autoridades locais para receber a família real. Para a ocasião, foi construída uma aldeia tubinambá em uma área da cidade perto do rio, com 300 participantes nus, dos quais 50 eram índios (FRANCO, 1976, p. 49). O relato e a gravura (ANEXO 4) de 1550 da encenação em Ruão representam as várias cenas da vida dos normandos e índios no Brasil: guerras entre tubinambás e tabajaras, corte e transporte de madeira para navios ancorados no cais da cidade e ainda cenas de aldeias queimadas. Não foi a única vez que a reconstituição da vida dos índios no Novo Mundo foi o tema escolhido para uma encenação para receber a elite do país (FRANCO, 1976, p. 49). As festas com temas do Novo Mundo ganharam o gosto e continuaram em 1564 em Troyes, quando da visita do rei à cidade. Em Bordéus, dois anos mais tarde, houve uma apresentação aos reis na qual os estrangeiros cativos de várias partes do mundo, incluindo índios do Brasil, discursavam para o rei e eram traduzidos por truchements ("cujos capitães arengavam diante do Rei, cada um em sua língua, ouvidos pelo turgimão, que os interpretava para Sua Majestade"; DENIS, 1944, p. 33)

A forma de difusão de informação sobre os tupinambás na França que nos interessará será a presença deles nos livros de viagem, gênero literário no qual se incluem as obras de Thevet, Lery, d'Abbeville e d'Evreux. O livro de viagem foi muito popular na França no século XVI, com temas sobre peregrinações à Terra Santa, ou viagens à Turquia e ao Novo Mundo. Em sua forma básica, o relato de viagem apresentava uma lista de topônimos, distâncias e algumas informações para fixar a memória de um acontecimento. No século XVI, o gênero se tornou mais variado na sua estrutura narrativa; misturou relatos de peregrinação e guia de lugares santos a um manual de meditação (GOMEZ-GÉRAUD, 2000, p. 22). No caso dos relatos de descoberta, o gênero combinava crônica e diário de bordo, como na obra de Gonneville, ou incluíam inserções de caráter enciclopédico, como as obras de Thevet e de Lery.

GOMEZ-GÉRAUD (2000, p. 17) analisa as marcas lingüísticas usadas nos livros de viagem para assegurar a autenticidade do relato sobre um mundo longínquo. Entre essas marcas, a autora aponta a presença de fragmentos da língua vernácula usada no local da viagem. 


\subsection{O papel das línguas estrangeiras no gênero do relato de viagem}

O tráfego de singularidades do Novo Mundo pelos viajantes podia se dar através de objetos, animais e sabores. Esse último pode ser acompanhado pela procura incessante do viajante MOCQUET (1617) para reencontrar no Novo Mundo um mel que havia levado para o rei em uma viagem anterior. Nesse elenco do objetos de curiosidades, entrava também a língua estrangeira.

O gênero dos relatos de viagem não chegou a desenvolver gramáticas ou vocabulários das línguas das regiões por onde passaram seus viajantes (GOMEZ-GÉRAUD, 2000). O papel da língua estrangeira nesse tipo de obra foi o de propor um guia para aprendizado da língua para quem fosse fazer a viagem ou ainda, no caso do Novo Mundo, o de fazer ver um mundo estranho que não poderia ser descrito sem apoio do vocabulário indígena (GOMEZGÉRAUD, 2000, p. 93). Na literatura sobre a França Antártica, em particular, os dados na língua tupi tiveram um papel importante na disputa entre Lery e Thevet por credibilidade. Por exemplo, Thevet ampliou os dados da língua tupi nas suas obras posteriores à publicação de Lery, momento a partir do qual se iniciou a polêmica entre os dois.

As formas pelas quais a língua tupi foi inserida no texto do relato de viagem foram: a) palavras e sentenças isoladas; b) transcrição de discurso direto na língua; c) orações cristãs na língua. O colóquio em tupi na obra de Lery, segundo Gomez-Géraud, apresentaria uma forma híbrida pouco comum nos relatos de viagem.

a) Palavras isoladas e sentenças na língua estrangeira em relatos de viagem

A principal forma de entrada das línguas estrangeiras no livro de viagem foi através de palavras isoladas e sentenças soltas ao longo do relato. Essa prática editorial foi responsável pela introdução de diversas palavras estrangeiras no léxico francês do século XVI (GOMEZ-GÉRAUD, 2000, p. 92). A presença das palavras emprestadas do léxico estrangeiro no relato de viagem se dava através do uso de 
itálicos para dar valores tipográficos diferenciados: "Acarapep, poison plat, lequel en cuisant jette une graisse jaune..." (LERY apud GOMEZGÉRAUD, 2000, p. 99)

Algumas das palavras estrangeiras passaram por um processo de lexicalização através da sua entrada na morfologia da língua francesa, como ocorreu com o termo tupi caoiun (bebida preparada com mandioca fermentada) usado também como verbo (caouiner) e na forma nominal (caou-inage) (GOMEZ-GÉRAUD, 2000, p. 100).

Gomez-Géraud analisa a forma da presença de palavras tupi no livro de Lery: são cerca de 140 palavras (sem incluir o capítulo referente ao colóquio em tupi), das quais 71 por cento são objetos da realidade que não têm equivalentes no léxico francês. São substantivos ou nomes próprios usados para se referir a) espécies naturais incomuns (animais, árvores, erva, etc.) (exemplo: sagouin); b) produtos ou utensílios que não se assemelhavam com outros objetos conhecidos (tacape) ou produtos alimentares transformados (caou-in); c) pessoas, divindades ou funções sem equivalentes na língua francesa (pajés); d) nomes comuns inseridos a título de informação de uma língua, apesar de terem equivalentes em francês (conomi-miri para menino pequeno); e) adjetivos, interjeição, verbos no imperativo (amabe para dê-me) (GOMEZ-GÉRAUD, 2000, p. 98).

A presença majoritária da língua estrangeira através de palavras isoladas e a ausência de produção de gramáticas ou vocabulários significa que o papel dessas línguas no livro de viagem foi o de nomear um mundo desconhecido e não por curiosidade lingüística. Ao citar as palavras estrangeiras, o viajante se põe como um observador do mundo real e não como um observador da língua (GOMEZ-GÉRAUD, 2000).

b) Teatralização da narrativa através da inserção do discurso direto em língua estrangeira no relato de viagem

A transcrição de uma passagem de discurso direto na língua estrangeira, incompreensível para o leitor do livro de viagem, tinha a função de estabelecer uma teatralização da narrativa, que teria o efeito de fazer seu leitor se sentir como na presença do estrangeiro 
(GOMEZ-GÉRAUD, 2000, p. 102). É o caso do trecho em que Thevet transcreve um diálogo de mulheres indígenas: ali o interesse não é a língua, pois não há informações sobre ela ao se fazer a tradução do trecho (GOMEZ-GÉRAUD, 2000, p. 102). Para reforçar a função de teatralização, a tipografia fazia uso de itálico.

No seu estudo do léxico tupi usado no livro de d'Abbeville, GARCIA (1927, p. 95) mostra que as traduções em francês propostas para os discursos em tupi não correspondiam integralmente ao texto.

c) Orações como singularidades nos livros de viagem e nas cosmografias (THEVET, 1584/1575, D'EVREUX, [1615]/1864)

Orações nas línguas estrangeiras - em particular o Pai Nosso aparecem como uma das formas de inclusão da língua estrangeira nos relatos de viagem, como em Thevet e d'Evreux. As orações em diversas línguas do mundo começam a ser publicadas como forma de "singularidade" de terras longínquas. Além de publicar o Pai Nosso em tupi, Thevet transcreveu uma versão dessa oração em etíope em Le grand insulaire (THEVET, 1586).

Outro exemplo do uso do Pai Nosso em diferentes línguas como curiosidade é o manuscrito de François Merlin de 1587, encontrado no acervo de Thevet (LESTRINGANT, 1991). Ali estão coletadas versões dessa oração em 29 línguas usando diferentes escritas (não inclui línguas do Novo Mundo). ${ }^{3}$

O Pai Nosso publicado por Thevet foi reeditado por Claude Duret em 1613 em uma obra sobre as origens das línguas, em um livro dedicado a Maurício de Nassau. Duret reproduziu o Pai Nosso em várias línguas (hebraico, caldeu, armênio, sueco, etc.) para fins de comparação lingüística. Essa oração, em diferentes línguas, se tornava um método para mostrar como as línguas eram similares ou diferentes.

O interesse intelectual por orações, como o Pai Nosso, deveria ter feito desses textos objeto de interesse no tráfego do exotismo do Novo Mundo e teria transformado os truchements e os viajantes em seus coletores. 
d) O colóquio de Lery como uma forma híbrida

Os colóquios, assim como os vocabulários, eram tipos de materiais para aprendizado da língua no contexto mercantil. O colóquio de Lery está incluído nesse gênero, ao apresentar diálogos a serem usados na chegada do visitante e ao orientar sobre o que dizer na troca de mercadorias. Porém, esse gênero de material lingüístico não costumava inserir análise da língua nas seqüências de enunciados. Um exemplo de material sobre a língua tupi produzido para uso entre marinheiros foi o vocabulário de 1540 (SANTOS, 2000), que fornece enunciados com sua tradução, mas sem apresentar nenhuma sistematização dos dados. GOMEZGÉRAUD (2000) chama atenção para a excepcionalidade do colóquio de Lery por incluir informações fonéticas, morfológicas e semânticas do tupi por meio de um narrador que faz comentários lingüísticos. Nenhum outro livro de viagem do Renascimento incluiu informações gramaticais. Tampouco nos materiais para uso entre marinheiros e pilotos se encontra esse tipo de dado lingüístico.

\section{O CATECISMO JESUÍTICO TUPI CONTEMPORÂNEO A THEVET E D'EVREUX}

A forma de identificação da origem intelectual das orações em tupi publicadas por Thevet e d'Evreux será através da correlação desses textos com os catecismos dos jesuítas. A apreciação dos catecismos jesuíticos tupi será tanto pela história da sua formação como pela comparação de uma das orações - como o Pai Nosso nas versões apresentadas pelos franceses e pelos jesuítas.

\subsection{História da formação do catecismo jesuítico tupi (1549-1618)}

O período em exame da história da formação do catecismo tupi dos jesuítas abrangerá de 1549 - data da chegada dos jesuítas e início das traduções religiosas para o tupi - até 1618, quando foi impresso o catecismo tupi de Antônio Araújo, o primeiro publicado pelos 
jesuítas portugueses nessa língua. O interesse nos itens seguintes do trabalho será saber:

a) O que sucedia na Companhia de Jesus no tocante à tradução de textos cristãos para o tupi no período que Thevet e d'Evreux passaram pelo Brasil?

b) Como se dava a circulação do catecismo entre missionários e índios?

c) Quais mudanças aconteceram ao longo da política lingüística jesuítica em relação ao catecismo em tupi?

\subsubsection{Dois focos de tradução da doutrina cristã para o tupi: São Vicente e Bahia}

Nos primeiros anos da evangelização, traduções em tupi de orações e diálogos de perguntas e respostas sobre questões teológicas, como Santíssima Trindade, foram feitas simultaneamente na Bahia e em São Vicente pelos jesuítas (CARDOSO, 1992a, p. 25). Nos dois lugares, essas traduções estiveram a cargo dos colonos portugueses bilíngües, participantes de uma cultura mestiça, igual à dos truchements. Serão esses colonos portugueses os que vão trazer para os jesuítas as informações culturais e lingüísticas sobre os índios. A diferença nos dois lugares foi quanto à forma de envolvimento do colono intérprete com a Companhia de Jesus: na Bahia como externos à Ordem, em São Vicente como internos.

a) Participação do colono como intérprete externo à Companhia de Jesus na Bahia

Algumas semanas depois de chegar ao Brasil, Nóbrega já procurava colonos bilíngües que pudessem traduzir textos cristãos ao tupi. A opção foi um colono em Porto Seguro, que estava há muitos anos na região, capaz de escrever tupi. O Padre Azpicuelta, acompanhado do Irmão Vicente Rodrigues, ficou responsável por acompanhar as traduções. Porém, como o "língua" (intérprete) também estava a serviço do governador, havia pouca disponibilidade dele para as funções de tradutor religioso. 
"Trabalhey por tirar em sua lingoa as orações e algumas praticas de N. Senhor, e nom posso achar lingoa que mo saiba dizer, porque sam elles tam brutos que nem vocabulos tem. Spero de as tirar o melhor que poder com hum homem que nesta terra se criou de moço, ho qual agora anda muy occupado em o que ho Governador lhe manda e nom esta aqui." (NÓBREGA, Bahia, abril de 1549, apud LEITE, 1956, t.1, p. 112)

"En esta Capitanía hallé un hombre de buenas partes, antigo en la tierra, y tenía don de escrevir la lengua de los Indios, que fué para mí grande consolación. Y assí lo más del tiempo gastava en dar sermones del testamento viejo y nuevo, mandamientos, pecados mortales y obras de misericordia, con los artículos de la fe, para me tornar en la lengua. Todo lo mandaré en la primera embarcación." (AZPICUELTA, Salvador, agosto de 1551 em LEITE, 1956 t.1, p. 279)

A identidade desse intérprete é incerta. CARDOSO (1992, t.I, p. 25), editor dos catecismos de Anchieta, acredita ser Bruza Espinosa, um "língua" que acompanhou posteriormente Azpicuelta numa expedição ao Rio São Francisco em 1553. Serafim Leite, por sua vez, o identifica como Diogo Alvares Caramuru. Desse último temos mais informações. Sua família tinha o perfil sociolingüístico dos casamentos interétnicos na colônia, nos quais as mulheres são monolíngües em tupi. Os jesuítas se referiam à mulher e às filhas de Caramuru como requerendo intérpretes para a confissão (NÓBREGA, Bahia, 1552 apud LEITE, 1956, t.I, p. 369).

Os jesuítas procuraram ter mais disponibilidade do tempo de Diogo Alvares Caramuru como intérprete para a evangelização dos índios através de salário. Nóbrega, com apoio do Bispo, procurou que ele recebesse um ordenado para acompanhar os jesuítas, tornandose um intérprete profissional para o discurso religioso em tupi.

"Ho Pe. Nobriga ordenou com o Bispo que fizesse com Diogo Alveres, por lingoa dos Indios Caramoru, aho qual tem grande credito os Indios por aver corenta ou ainda sinquoenta annos que anda entre elles e ser velho honrrado, que andasse pellas Aldeas com os Padres, prometendo-lhe ordenado d'El-Rei, o que ao Bispo pareceu muito bem e logo ho poz em obra e lhe falou. E assi se fará, e está concertado ir hum dia destes por todas as Aldeas a pregar 
contra ha abusão que está semeada antre elles e declarar-lhes a verdade, e á-de sser pai dos que se converterem." (Francisco Pires, Bahia, 1552 apud LEITE, 1956, t.I, p. 398)

"Hé Diogo Alvarez, muito acreditado entre este gentio. Andará comnosco pellas Aldeas pregando; favoreça-o V.R. de llá com fazer que El-Rei lho escreva e agardeça e lhe ordene algum pobre ordenado por isso, pois tão bem empregado será." (Manuel da Nóbrega, Bahia, setembro de 1552, apud LEITE, 1956, t.I, p. 409)

Outra forma incentivada por Nóbrega para adquirir conhecimento da cultura e língua tupi para a pregação na Bahia foi através da criação de confrarias (Vicente Rodrigues, Bahia, setembro de 1552 apud LEITE, 1956, t.I, p. 410), formadas pelos órfãos portugueses trazidos por Nóbrega e pelos filhos mestiços dos colonos portugueses.

Em 1553, Azpicuelta conta que, antes de viajar para a região do rio São Francisco, havia deixado para os outros jesuítas (Ambrosio Peres e Irmão Blazquez) várias orações na língua do Brasil, com os mandamen-tos, pecados morais, confissão geral, princípio do mundo e encarnação (AZPICUELTA, Porto Seguro, setembro 1553 apud LEITE, 1956, t.II, p. 9).

Na Bahia, os jesuítas não conseguiram criar um grupo de línguas disponíveis para evangelização nesse período inicial. Na época em que Azpicuelta estava no rio São Francisco, Nóbrega informava ao Rei de Portugal que não se estava convertendo os índios "por falta de lingoas" (NÓBREGA, São Vicente, 1553 apud LEITE, 1956, t.II, p. 16)

b) Participação do colono como intérprete interno à Companhia de Jesus em São Vicente

São Vicente era uma sociedade baseada na mão de obra indígena e fundada na mestiçagem entre portugueses e índios. Antônio Vieira descreve a região dessa forma:

"É certo que as famílias dos portugueses e índios de São Paulo estão tão ligadas hoje humas às outras, que as mulheres e os filhos se criam mystica e domesticamente, e a lingua que nas ditas famílias se fala he a dos indios, e a portuguesa a vão os meninos aprender à escola." (Antônio Vieira apud HOLANDA, 1978, p. 88) 
Nóbrega justificava a fundação de uma casa jesuítica em São Vicente por dispor de irmãos-línguas ali ("nesta Capitania nos proveo de instrumentos para isso, que são alguns Irmãos línguas, e por estas razoes nesta Capitania nos ocupamos mais que nas outras", NÓBREGA, 1553 apud LEITE, 1956, t.II, p. 16). A diferença em relação à Bahia foi a absorção do colono bilíngüe como membro da Companhia de Jesus. Os primeiros foram Pero Correia e Manuel Chaves Em 1554, Anchieta cita cinco nomes de irmãos línguas em São Vicente: Pero Correia, Antônio Rodrigues, Manuel de Chaves, Fabiano de Lucena, Antônio do Vale (Leonardo do Vale) (ANCHIETA, São Paulo, setembro de 1554 apud LEITE, 1956, t.II, p. 104). Esses "irmãos-línguas" estavam destinados a serem coadjutores espirituais, ou seja, com votos para administrarem os sacramentos (confessar, batizar, etc.).

O grupo nomeado por Anchieta como intérprete não apresentava o mesmo perfil requisitado na Metrópole para receber os votos de coadjutor espiritual. Fabiano de Lucena, por exemplo, não continuou na Ordem. Ele já se encontra ausente do catálogo jesuítico de 1568. Manuel Chaves e Pero Correia não sabiam latim e tinha sido pedido dispensa dessa exigência para receberem os votos. De Manuel Chaves, diz Nóbrega em 1557:

"He bom filho e mui humilde, e que tem servido muito a seus
irmãos, e o milhor lingoa que temos; trabalhei de o encaminhar a
ser clerigo pois sabia o latim da terra: se ho for, sera mui idiota, mas
entre outros que mais saibão se sofre; este podera ser coadjutor
espiritual depois de ordenado." (NÓBREGA, 1557 apud LEITE, 1956,
t.II, p. 418)

Para Pero Correia, o mais conceituado como "língua" desse primeiro grupo, era ainda necessário ter dispensa da acusação de ter morto índios, quando era negociante de escravos indígenas. 


\begin{tabular}{|c|c|c|c|c|c|c|}
\hline Nomes & $\begin{array}{l}\text { Nasci- } \\
\text { mento } \\
\text { e morte }\end{array}$ & $\begin{array}{l}\text { Entrada } \\
\text { na } \\
\text { Ordem }\end{array}$ & $\begin{array}{l}\text { Tipo de } \\
\text { relação } \\
\text { com a } \\
\text { sociedade } \\
\text { colonial }\end{array}$ & $\begin{array}{l}\text { Conheci- } \\
\text { mento de } \\
\text { latim }\end{array}$ & $\begin{array}{l}\text { Localização } \\
\text { no catálogo } \\
\text { jesuítico de } \\
1558 \text { (LEITE, } \\
1956, \text { t.II, } \\
\text { p. } 460 \text { ) }\end{array}$ & $\begin{array}{l}\text { Localização } \\
\text { no catálogo } \\
\text { jesuítico de } \\
1568 \text { (LEITE, } \\
1956, \text { t. IV, } \\
\text { p. } 473 \text { ) }\end{array}$ \\
\hline $\begin{array}{c}\begin{array}{c}\text { Antônio } \\
\text { do Vale } \\
(=\text { Leonardo } \\
\text { do Vale })\end{array} \\
\end{array}$ & 1538-1591 & 1553 & $\begin{array}{l}\text { cresceu } \\
\text { no Brasil }\end{array}$ & $\begin{array}{l}\text { "algum" } \\
\text { (LEITE, } \\
1956, \text { t. IV, } \\
\text { p. 476) }\end{array}$ & Bahia & Bahia \\
\hline $\begin{array}{c}\text { Antônio } \\
\text { Rodrigues }\end{array}$ & 1516-1568 & 1553 & soldado & & Bahia & \\
\hline $\begin{array}{l}\text { Fabiano } \\
\text { de Lucena }\end{array}$ & $\longrightarrow$ & 1551 & $\begin{array}{l}\text { [não } \\
\text { continuou } \\
\text { na Ordem] }\end{array}$ & & $\begin{array}{l}\text { Espírito } \\
\text { Santo }\end{array}$ & \\
\hline $\begin{array}{c}\text { Manuel } \\
\text { de Chaves }\end{array}$ & $1514-1590$ & 1550 & colono & $\begin{array}{l}\text { "muy idiota" } \\
\text { (LEITE, } \\
1956, \text { t.II, } \\
\text { p. 418) }\end{array}$ & São Vicente & Piratininga \\
\hline $\begin{array}{c}\text { Pero } \\
\text { Correia }\end{array}$ & $?-1554$ & 1550 & $\begin{array}{l}\text { colono } \\
\text { chegou } \\
\text { ao Brasil } \\
\text { em } 1533\end{array}$ & $\begin{array}{l}\text { "não soy } \\
\text { latino" } \\
\text { (LEITE, } \\
1956, \text { t. I, } \\
\text { p.440) }\end{array}$ & - & - \\
\hline
\end{tabular}

FIGURA 1 - Jesuítas-línguas em São Vicente em 1554 (ANCHIETA apud LEITE, 1956, t. II, p. 104)

Foi, possivelmente, graças a esse grupo de intérpretes que Anchieta pôde fazer a gramática tupi em um curto período de tempo (um ano e meio) (FIG. 1). Em 1554, Anchieta menciona que já havia orações e doutrina em tupi traduzidas em São Vicente (CARDOSO, 1992, p. 21).

c) Modo gentio de pregar

Um ponto comum entre o grupo de jesuítas na Bahia e em São Vicente na forma de evangelização nesses primeiros anos foi o de terem pregado em tupi, durante as missões itinerantes, no espaço e tempo tradicionais dos pajés e dos profetas. Pero Correia fazia suas pregações 
nas horas próprias dos pajés e dos "senhores da fala", figuras da sociedade tupi reconhecidas como possuidoras do dom da oratória.

"Por todos os lugares e povoações que passavamos me mandava preguar-lhes nas madruguadas, duas horas ou mais; e era na madruguada porque emtão era custume de lhe pregarem os seus Principaes e Pagés, a que elles muyto creem." (Pero Correia, São Vicente, 1551 apud LEITE, 1956, t.I, p. 220)

$\mathrm{Na}$ Bahia, o Pe. Azpicuelta Navarro também era mencionado como fazendo uso de formas gestuais e de oratória tupi na pregação cristã, além de usar música e dança para as orações, como o Pai Nosso.

"[Navarro] começava a despejar a torrente da sua eloquência, levantando a voz, e prègando-lhes os mistérios da fé, andando em roda dêles, batendo o pé, espalmando as mãos, fazendo as mesmas pausas, quebras e espantos costumados entre seus prêgadores, pera mais os agradar e persuadir." (LEITE, 1938, t.II, p. 299)

"El Pater Noster tiré en modo de sus cantares para que más presto aprendiessen y gustasen, principalmente para los mochachos, a los quales enseno que las digan sobre los dolientes." (João Azpicuelta, Bahia 28 de março de 1550, apud LEITE, 1956, t.I, p. 180).

"Después desto que los tienen ajuntados, assi baylando y cantando, dizenles la passión de nuestro Señor, mandamientos, Pater Noster, Credo e Salve Regina en su lingua." (Pedro Doménech, Lisboa, outubro, 1552 apud LEITE, 1956, t.I, p. 417)

A inclusão do "modo gentio" na evangelização foi possível nesses primeiros anos devido à forte presença na ordem jesuítica dos colonos bilíngües, os responsáveis pelo conhecimento cultural e lingüístico sobre os índios trazidos para a Companhia de Jesus. A estratégia de aproximar o discurso cristão em tupi da oratória tupi dos pajés estava alinhada com a política do Provincial Manuel da Nóbrega, defensor da inserção de elementos da cultura tupi na forma de evangelização. Essa posição de Nóbrega foi motivo de enfrentamento com o Bispo Fernandes que se opunha a essa linha de evangelização. 
As explicações de Nóbrega a seus superiores em Portugal surgem em resposta às acusações feitas pelo Bispo:

\begin{abstract}
"Se nos abraçarmos com alguns custumes deste gentio, os quais não são contra nossa fee catholica, nem são ritos dedicados a idolos, como hé cantar cantigas de Nosso Senhor em sua lingoa pello seu toom e tanger seus estromentos de musica que elles [usam] em suas festas quando matão contrairos e quando andão bebados; e isto pera os atrahir a deixarem os outros custumes esentiais e, permitindolhes e aprovando-lhes estes, trabalhar por the tirar os outros; e assi o pregar-lhes a seu modo em certo toom andando passeando e batendo nos peitos, como elles fazem quando querem persuadir alguma cousa e dizê-la com muita eficacia; e assi trosquiarem-se os meninos da terra, que em casa temos a seu modo. Porque a semelhança é causa de amor." (Manuel da Nóbrega a Simão Rodrigues, Bahia, 1552 apud LEITE, 1956, t.I, p. 407)
\end{abstract}

\title{
6.1.2. Estandardização do catecismo tupi pelo modelo de São Vicente
}

O estado inicial de diversidade de traduções cristãs em tupi entre as missões acabou a partir de 1556, quando começou haver a uniformização do discurso cristão em tupi segundo o modelo usado em São Vicente. Em 1555, Luís Grã, com ajuda dos línguas de São Vicente, estabeleceu uma versão única para todas as missões (CARDOSO, 1992, t.I, p. 6).

Não é difícil imaginar que os jesuítas em São Vicente e na Bahia conhecessem o que um e outro faziam através de cartas e dos permanentes remanejamentos dos missionários ao longo da costa. Anchieta foi um dos que tomaram contato com as traduções dos dois locais, pois ao chegar ao Brasil pela Bahia em julho de 1553, ele conheceu Azpicuelta e Vicente Rodrigues. Em dezembro daquele ano, Anchieta chegava a São Vicente onde entrou em contato com o grupo de intérpretes nomeados em sua carta de 1554. De alguns deles, Anchieta foi professor de gramática. O fato de que os dois grupos conheciam as mútuas traduções não impedia que continuassem usando suas próprias versões. Até esse momento não havia esforços internos pela uniformização da doutrina cristã nas missões. 
A partir de 1556, não apenas as orações e textos cristãos em tupi feitos em São Vicente foram levados para as outras missões como também alguns dos seus "línguas" foram distribuídos a outros pontos da costa. Na FIG.1, por exemplo, vemos que Antônio Rodrigues foi para a Bahia e Fabiano de Lucena para a aldeia de Espírito Santo para se ocuparem ambos da evangelização dos índios.

"Aquy (Espirito Santo) se comensó luego a senbrar a palavra del sagrado Avangelio, dando nuestro Padre el carguo desto a dos Hermanos que sabían la lengua brasilica, y que la tinían ya mucho tienpo exercitado en la Capitanía de S. Vicente." (Antônio Blazquez, Bahia, agosto de 1556 apud LEITE, 1956, t.II, p. 298)

Na Bahia, a presença dos intérpretes originários de São Vicente e dos seus textos em tupi levou ao abandono as orações propostas por Navarro. Antônio Rodrigues, por exemplo, ficou encarregado de reformular as traduções deixadas por Navarro, consideradas insatisfatórias em comparação com aquelas de São Vicente.

"Con las más oraciones que de Sant Vicente vinieron, aprenderemos todo lo que conviniere para la conversión desta guentilidade." (Antônio Blazquez, Bahia, agosto de 1556 apud LEITE, 1956, t.II, p. 301)

"O derradeiro foy o Irmão Antônio Rodrigues, a quem fez mestre de cathecuminos polas partes que pera isso tem do Senhor, tendo também anexo a isto o cargo de fazer a doutrina à gente de fora, o que fez todo o tempo que em a cidade esteve com grande copia de indios e indias Era pera louvar ao Senhor como então crecia o numero delles, porque até então não se tinha ensinado com tanto concerto nem tinhamos as orações da doutrina tam bem tresladadas e nao avia senão soo o Pe. Navarro que, dado que sabia a língua razoavelmente, todavia não tinha tanta noticia das cousas tocantes a este negocio. Mas agora que o Irmão lhes começou a declarar en sua lingua os artigos da fee e as mais orações, e fazendo-lhes praticas e declarações sobre ellas, lhe sobreveo hum novo fervor, engodados, segundo eu cuido, pola novidade da cousa." ( Irmão Blazquez, Bahia, janeiro de 1557 apud LEITE, 1956, t.II, p. 348)

Não se conhecem as traduções em tupi propostas por Azpicuelta, mas por um trecho de uma carta de um dos jesuítas na Bahia, Antônio 
Blazquez, podemos conhecer pelo menos uma diferença entre a versão usada na Bahia e aquela que veio de São Vicente. Blazquez conta que depois da chegada de Antônio Rodrigues, deixaram de usar na oração do Sinal da Cruz em tupi o termo "Santa Joaçaba" como tradução de "Santa Cruz" e passaram a usar a expressão portuguesa como empréstimo.

"E dado que ao principio tinhão empacho de dizer 'santa joaçaba'que em nossa lingoa quer dizer: polo sinal da cruz, por lhes parecer aquillo gatimanhos, ya agora estão destros em se santiguar e sabem muitos as orações de choro." (Irmão Blazquez, Bahia, 1557 apud LEITE, 1956, t. II, p. 348)

O pequeno trecho sugere diferentes concepções de tradução religiosa entre o grupo da Bahia e de São Vicente.

a) Pregar aos índios como aos brancos (1574)

Um quarto de século depois do início da evangelização entre os índios, a política jesuítica adotada não se enquadrava mais com aquela defendida por Nóbrega de usar modos gentios na pregação. O ideal era o de pregar aos índios como aos brancos.

"En este [año de 1574] se vio notable augmento en el bien espiritual de los Índios en todas las quatro aldeas em que los nros [nuestros] residen... introduzese tambien entre ellos la maneira de predicar que se usa entre los blancos, para que, en todo vayan ya perdiendo las costumbres de sus antepassados e afecionanandose a los nuestros." (História.... 897, p. 112)

Algumas das mudanças desse período foram:

i) proibição em 1579 da entrada na Companhia de Jesus dos "nascidos no Brasil” (LEITE, 1938, t.II, p. 432). A proibição excluía a entrada do principal grupo que deu origem aos intérpretes entre os jesuítas. Os colonos bilíngües admitidos na ordem haviam sido os responsáveis até então pela introdução da cultura tupi na forma de pregação;

ii) o espaço de pregação não era mais o usado pelos "senhores da fala" tupi. As missões não eram mais itinerantes e as pregações se faziam nos púlpitos das igrejas construídas nas aldeias jesuíticas; 
iii) o catecismo tupi passou a ter como modelo o catecismo de Marcos Jorge (1602), destinado ao uso entre as crianças portuguesas. Esse catecismo, impresso em 1566 em Portugal, foi traduzido para o tamul (579), japonês (1592), concani (1622) e língua do Congo (1624). Em Portugal, ele havia sido amplamente divulgado, recebendo sucessivas impressões com recursos reais e sofrendo várias modificações ao longo dos séculos. O fato de esse catecismo português ser dirigido às crianças indicava que essa era a concepção da evangelização da população indígena adulta.

"El Pe. Leonardo compuso este año [1574] una doctrina en la lengua del Brasil quase tresladando la que hizo el Pe. Marcos Jorge de buena memória. Costo mucho trabajo mas entiendese que sera provechoso. Tambien se hizieron los aparejos para confessar baptizar y ayudar a bien morir y un confessionario en la lengua." (História .... 1897, p. 117)

Leonardo do Vale fazia parte do grupo de línguas citado por Anchieta em São Vicente em 1554. Seu nome como tradutor do catecismo indica que o grupo de línguas de São Vicente liderava na responsabilidade de elaborar o catecismo tupi. A presença de Leonardo do Vale na Bahia como professor de tupi no Colégio dos jesuítas indicava também que São Vicente continuava sendo o celeiro de línguas para a Bahia.

b) Tentativas frustradas de impressão do catecismo tupi:

Houve vários pedidos para a impressão do catecismo tupi por parte dos jesuítas no Brasil (em 1575, 1585 e 1592) (LEITE, 1938, t.II, p. 557 e 552), todos eles sem sucesso. Todas as solicitações alegavam que, com a impressão do catecismo, se conservaria o texto sem modificação. Uma carta de Beliarte, de 1592, mostra o papel da impressão como forma de estandardização dos catecismos coloniais.

"E eu, da minha parte, peço também com tôdas as veras o mesmo.

Quanto à Doutrina, quarenta anos há que se compôs, e até agora sempre se ensinou, apurando-se e emedendando-se assim no tocante à Teologia como na língua. E porque parece que não há já que emendar, como os melhores línguas, que há, dizem; e no 
Teologia estamos certos: e, com se imprimir, será mais fácil tê-la todos, aprendê-la e ensiná-la, se pede a V.Paternidade dê para isso licença, porque pelo trabalho de a escrever muitos deixam de a ter, e os que a teem, não a teem certa; e cada um, se está um pouco adiantado na língua, lhe parece que se poderia dizer isto ou aquilo melhor, e assim a querem emendar a seu gôsto; com a ver impressa, entenderão que não há que emendar a seu gôsto." (Marzal Beliarte, Bahia, 20 de setembro de 1592 apud LEITE, 1938, t. II, p. 558)

A primeira impressão do conjunto de orações em tupi dentro de um catecismo - e não em um livro de viagem - se deu por iniciativa da colonização hispânica e não portuguesa. Em 1607, os textos religiosos em tupi foram publicados no interior da obra "Rituale Seu Manuale Peruanum", que continha catecismos nas três línguas gerais do Arcebispado de Lima (quechua, aymara e guarani). Esse livro foi resultado do Terceiro Concílio de Lima (1584-1585), que havia reforçado a necessidade de uniformizar a evangelização pela elaboração de um texto cristão padrão nas línguas gerais do Arcebispado de Lima.

Apesar da política jesuítica de estandardização do catecismo tupi, os jesuítas no Brasil conseguiram publicar o primeiro catecismo tupi à custa dos padres do Brasil" apenas em 1618 (ARAÚJO, 1952). O catecismo tupi havia levado cerca de 70 anos para ser impresso, processo bastante lento se for comparado com os catecismos em nahuatl e quechua, na América Hispânica, que receberam sucessivas impressões desde o século XVI. O contexto político favorecedor da impressão do catecismo tupi em 1618 parece ter sido o plano jesuítico de atuar na Amazônia, recém-ocupada pelos portugueses através da tomada de São Luís dos franceses e da fundação de Belém. O prólogo do catecismo de Antônio Araújo (1618) faz alusão ao uso daquela obra na evangelização da população indígena da Amazônia. A estandardização do texto religioso em tupi abarcava tanto o seu uso no Estado do Brasil como no Estado do Maranhão e Grão-Pará, como menciona o prólogo do catecismo de Antônio Araújo:

"Agora pera que os que escolhe pera obreiros da altíssima empresa da salvação dos poucos Índios, que escaparam, e se vão tendo aos 
mares das tribulaçoens [....], tenhão com que os possão perfeiçoar, \& reduzir os muitos, que o novo descubrimento do Maranhão lhes està offerecendo, ordenou por via do Reverendo padre Provincial Pedro de Toledo [...] se imprimir o Catecismo, que nesta lingoa antigoamente composerão alguns Padres doctos, \& bons línguas." (ARAÚJO, 1618 [1952])

c) Formas de difusão dos textos cristãos em tupi entre os índios

A escrita em tupi elaborada pelos jesuítas ao longo do processo de tradução religiosa não era para uso dos índios. Ela era destinada aos jesuítas como forma de aprendizado do texto religioso em tupi. A forma de aprendizagem dos textos cristãos pelos índios era através da memorização. O ensino das orações era pela contínua repetição nas horas de doutrina ("Dão conta das coisas da fé por um formulário de perguntas [...] fazendo um de mestre os outros de discípulos, repetiram por ordem a Doutrina Cristã" (ANCHIETA, 1556 apud CARDOSO, 1992b, p. 22).

Saber de memória as orações e as respostas às perguntas sobre a Santíssima Trindade eram condições para ser batizado (CARDOSO, 1992, t.II, p. 22). Esse estilo de evangelização pela memorização continuou presente ao longo do século XVII, como apontava um holandês no Nordeste:

"Há pouco conhecimento de Deus e do nosso Salvador entre os brasilianos, e não sabem senão nomear Deus e Jesus-Cristo e sua Nossa Senhora como chegaram a aprender com os padres; sabem, entretanto, o Padre Nosso e o Credo e recitam-nos em sua língua , e nada mais. São poucos os que dão as razões da sua fé e em que fundamentam a Salvação." (DUSSEN, 1947)

\subsection{Comparação de oração em tupi de Thevet e d'Evreux com a versão correspondente dos jesuítas}

a) Inventário dos catecismos jesuíticos contemporâneos a Thevet e d'Evreux

Versões de textos religiosos em tupi dos jesuítas (até 1618): 
1. [1553-1595] Período presumível de formação (manuscritos):

- Diálogo da Fé (Anchieta 1988)

- Doutrina cristã (Anchieta 1992 t.I)

- Doutrina autógrafa portuguesa (Anchieta 1992 t.II)

2. 1607

Rituale seu Manuale Peruanum et forma brevis administrandi apud Indos Sacrosanta Baptismi, Poenitentiae, Eucharistide, Matrimonii et Extremae Unctions. Luís Jeronimo Ore Impresso (Itália)

3. 1618

Araújo, Antônio. Catecismo na língua brasílica (1952). Impresso. (Portugal)

A comparação de uma única oração, o Pai Nosso, será a forma de verificar se as orações em tupi dos dois franceses teriam procedência jesuítica. Essa oração foi um dos textos mais cristalizados da evangelização colonial, se considerarmos que a versão usada no Sul, no século XVI (ANCHIETA, 1988), foi a mesma usada pelos jesuítas na Amazônia no século XVIII. ${ }^{4}$

Das cinco versões jesuíticas de catecismo tupi, apenas três dispõem do Pai Nosso:

- ANCHIETA. Diálogo da fé(1988):

É uma cópia de 1730 de um catecismo assinado por ANCHIETA. O manuscrito não contém a seção de orações em tupi, mas entre os diferentes diálogos de perguntas e respostas sobre a doutrina cristã, há um sobre o Pai Nosso. ${ }^{5}$ Por esse diálogo é possível recuperar o texto inteiro dessa oração e será por ele que nos basearemos na comparação com Thevet e d'Evreux.

- ORE (1607)

O livro "Rituale Seu Manuale Peruanum" contém, no final da obra, orações e listas de sacramentos, pecados e mandamentos em tupi. Possivelmente foi uma cópia do catecismo tupi que três jesuítas 
do colégio de São Vicente (Thomas Field, Juan Saloni e Manuel Ortega) levaram para a evangelização no Paraguai em 1586.

- ARAÚJO (1618):

Seu prólogo menciona que o texto em tupi era uma continuidade a uma versão que se usava nas missões havia um longo tempo, com alguns acréscimos. Possui o usual em um catecismo: as orações, as listas de mandamentos e de sacramentos e diálogos de perguntas e respostas sobre pontos da doutrina cristã. Além dessas seções, contém um vocabulário com termos de parentesco para auxiliar o confessor, um calendário dos dias santos acompanhado pela exortação a ser feita em tupi e, ainda, instruções sobre a ortografia utilizada. Era uma coletânea de materiais elaborados pelas sucessivas gerações de jesuítas-línguas.

Essas três versões de Pai Nosso serão o corpus de comparação com as versões de Thevet e d'Evreux.

b) Comparação de orações em Thevet com as versões jesuíticas

Thevet é o que se distancia mais das três versões jesuíticas do Pai Nosso contidas em ANCHIETA (1988), ORE (1607) e ARAÚJO (1952), porém ainda assim conserva sinais de sua procedência jesuítica, como se pode ver pelos trechos semelhantes (ANEXO 1).

A origem jesuítica do texto de Thevet está marcada pela presença de palavras portuguesas nas orações como ("Maria" e "Espirito Santo"), sem que ele use a tradução francesa desses termos, como aparecerá mais tarde na versão de d'Evreux.

Uma das diferenças do Pai Nosso em Thevet em relação à versão jesuítica é no tocante ao uso de empréstimos lexicais do português. Na versão de Thevet, não há os empréstimos lexicais como "tentação", "reino" e "amém", presentes no Pai Nosso de ANCHIETA (1988), ORE (1604) e ARAÚJO (1952). Diferente das demais traduções dos jesuítas em outras partes do mundo (Índia, Japão e Congo), a versão de Pai Nosso em Thevet traduz "amém" ("Emona né toico"). Geralmente nos demais catecismos portugueses, usava-se "amém" sem fazer uso de traduções. 
c) Comparação de orações em d'Evreux com as versões jesuíticas:

As orações em tupi publicadas por D'EVREUX (1615) não apenas são procedentes dos jesuítas como também contemporâneas da versão publicada por ARAÚJO (1618). A diferença do texto de d'Evreux está em usar uma ortografia com base no francês (ou para $u$ dos textos portugueses) e o de traduzir para o francês os termos portugueses presentes nas orações (por exemplo usar reigne no lugar de reino).

\section{ALGUMAS CONCLUSÕES}

O trabalho sobre a origem intelectual das orações em tupi na obra de Thevet e d'Evreux procurou traçar a passagem das orações em tupi de catecismos jesuíticos para publicações em livros com relato de viagem, no qual as orações eram incluídas com valor de singularidade do Novo Mundo.

a) Origem jesuítica portuguesa:

- As orações em tupi publicadas por Thevet e d'Evreux são procedentes da Companhia de Jesus, porém os dois franceses publicaram diferentes versões jesuíticas desses textos religiosos. A versão de d'Evreux era coincidente com aquela que se tornou padrão nas missões jesuíticas através da impressão do catecismo de Antônio Araújo. A versão de Thevet aponta uma versão jesuítica desaparecida no interior da Ordem. Dessa forma, os textos em tupi de Thevet e d'Evreux guardam pistas preciosas para o estudo da história do catecismo tupi da Companhia de Jesus.

- O quadro do parentesco entre os textos franceses e portugueses seria o seguinte:

\section{Parentesco entre as orações em tupi dos jesuítas e dos franceses}

\begin{tabular}{|c|c|}
\hline $\begin{array}{c}\text { [não se conhece nenhum } \\
\text { texto correspondente] }\end{array}$ & Thevet \\
\hline $\begin{array}{c}\text { Ore } \\
\text { Antônio Araújo } \\
\text { Anchieta }\end{array}$ & d'Evreux \\
\hline
\end{tabular}


- As orações de Thevet e d'Evreux apresentam dois momentos diferentes da política de tradução seguida pelos jesuítas. O Pai Nosso publicado por Thevet não utiliza nenhum empréstimo em português. A versão do Pai Nosso em d'Evreux, que correspondeu à versão que foi utilizada até a expulsão dos jesuítas, incluía a tradução francesa dos termos "reino" e "amém". Essa mesma diferença em relação à política de tradução se encontra nas demais orações de Thevet (Credo e Ave Maria), que possuem menos termos emprestados que a versão oficial jesuítica.

- Uma hipótese é que o texto publicado por Thevet representaria a versão em uso na Bahia antes de o texto ter sido substituído pela versão usada em São Vicente. Perguntar-se-á se as orações em tupi não estariam entre os papéis que Azpicuelta conta, em 1552, que haviam sido roubados pelos franceses em um navio a caminho de Portugal (LEITE, 1956, t.I, p. 417) e dessa forma chegado às mãos dos franceses? Um ponto coincidente entre a política de tradução implícita nas orações publicadas em Thevet e naquela usada na Bahia era o de usar poucos empréstimos do português. Como se viu, a versão de Azpicuelta Navarro prefere "Santa Joaçaba" em vez de "Santa Cruz", como vai adotar a versão de São Vicente para a Oração do Sinal da Santa Cruz.

b) Difusão européia das orações tupi através dos truchements normandos:

- Se as orações em tupi de Thevet e d'Evreux são de origem jesuítica, sua difusão em publicações na Europa se fez a partir da intermediação dos truchements. Eles são os que transmitem para os intelectuais franceses (cosmógrafos como Thevet, romancistas como Montaigne, missionários como d'Evreux) as informações sobre os tupinambás. Os truchements se tornam importantes como fonte desse conhecimento lingüístico necessário para o gênero literário dos livros de viagem, no qual se incluem as obras de Thevet, Lery e d'Evreux. 
- A circulação do texto jesuítico português para o domínio dos franceses inimigos pode ter ocorrido através de índios cristianizados pelos portugueses e que eram escravos dos franceses. O conhecimento das orações por parte dos índios era por memorização e não por documento escrito.

c) Dois ritmos de impressão das orações em tupi: no relato de viagem e no catecismo:

- A impressão do primeiro catecismo tupi dos jesuítas portugueses levou cerca de 70 anos para vir a ser concretizada, em oposição aos livros com relatos de viagem, que poderiam vir a ser publicados apenas um ano depois de findas as viagens. Um exemplo são os livros de D'EVREUX (1864) e de D'ABBEVILLE (1945).

- O diferente ritmo de impressão se devia aos diferentes procedimentos para a sua publicação. Enquanto o livro de viagem não precisava de permissões especiais para ser impresso, a publicação de um catecismo requeria vários níveis de permissão (do Provincial no Brasil, em Portugal, do Santo Ofício, etc.).

d) Empréstimos lexicais nos dois gêneros literários (catecismo e relato de viagem):

- Os dois gêneros literários em questão incorporam empréstimos lexicais no seu texto. No relato de viagem francês sobre o Brasil houve a introdução do léxico tupi como marca de autenticidade do que foi relatado (GOMEZ-GÉRAUD, 2000). Nos catecismos, ao contrário, os empréstimos lexicais eram as palavras portuguesas incluídas no texto de uma oração, por serem consideradas intraduzíveis.

- Alguns léxicos se mantiveram fixos na forma em que aparecem nos textos: a tradução para Deus foi sempre "tupã", enquanto o Espírito Santo foi sempre referido em português.

“...el Spiritu Sancto, para el qual nunca hallamos vocablo proprio ni circunloquio bastante, aunque no lo sabía nombrar sabíalo empero creer assí como se lo deziamos." (ANCHIETA, São Vicente, abril de 1563 apud LEITE, 1956, t.III, p. 560) 
- Alguns conceitos cristãos variaram nos catecismos, apontando diferentes posições na Companhia de Jesus em relação a se deviam usar empréstimos do português ou procurar paráfrases em tupi. Por exemplo, na versão do Credo em ANCHIETA (1992, t.I), a idéia de virgem aparece pelo termo em português, e, posteriormente, em Antônio Araújo, cria-se uma paráfrase para o conceito: "abá bykaguéreyma" (= sem toque anterior de homem) (CARDOSO, 1992, t.I, p. 142).

\section{NOTAS}

${ }^{1}$ Pesquisa realizada em maio de 2000 dentro do Projeto "Rede de Estudos das Línguas Indígenas do Brasil" (CAPES-COFECUB), coordenado por Marília Facó (Museu Nacional/UFRJ) e Michel Launey (CELIA/CNRS). Agradeço as discussões e indicações bibliográficas de Gerald Taylor, Silvio Liuzzi, César Itier, Toru Maruyama e Alix Cooper. A Eliane Camargo, agradeço a leitura paciente e minuciosa do texto.

2 Não há referência a que grupos étnicos pertenciam Yapoco ou Grande Raio.

${ }^{3}$ MERLIN (1587). Recherche de plusieurs singularités par François Merlin controlleur général de la maison de Seu Madame Marie Elisabeth fille unique de Seu Roy Charles dernier que Dieu absolue. Portraictes \& escrotes par Jacques Cellier demourant a Reims. Commence le 3 jour de Mars 1583. Et achevé le 10 septembre 1587.

Outros exemplos desse tipo de coletânea poliglota de Pai Nosso:

- Chamberlaynius Joannes. Oratio Dominica in diversis omnium fere gentium linguas versa et propriis cujusque linguae characteribus expressa. Una cum dissertationibus nonnullis de Linguarum Origine, variisque ipsarum permutationibus. Editore Joanne Chamberlaynio Anglo-britanno, Regiae Societatis Londinensis \& Berlolinensis Socio. Amstelaedami, Typis Guillelmi \& Davidis Goerei. MDCCXV (citado por MELIA, 1969).

- Marcel, J J. Oratio dominica CL linguis versa, et propriis cujusque linguae characteribus plerumque expressa; edente JJ Marcel, Typographii Imperialis Administro Generali. Parisiis, Typis Imperialibus. anno repar. Sal. 1805. Imperique Napoleonis Primo. folha 142 oração em tupi (citado por MELIA, 1969).

${ }^{4}$ Para exemplos de Pai Nosso em tupi usado pelos jesuítas na Amazônia, ver ECKART (1778), FAY (1942) e manuscritos do século XVIII publicados por AYROSA (1950).

${ }^{5}$ Esse diálogo reproduz trechos do catecimo de JORGE (1602).

${ }^{6}$ Versão com grafia modernizada. 


\section{REFERÊNCIAS BIBLIOGRÁFICAS}

D'ABBEVILLE, Claude.L'arriuee des peres capucins, Ela conuersion des saumages à nostre saincte foy. / Declaree par le r.p. Claude d'Abbeuille predicateur capuçin, Paris, chez Iean Nigaut ruë S. Iean de Latran à l'Alde, 1613. 16 p.

D'ABBEVILLE, Claude. Les fruicts de la mission des reuerends peres capucins en l'isle de Maragnan.: Comment la croix fut plantée, Ela terre beniste, dequoy s'est ensuiuy la conuersion de plusieurs indiens sauuages Topinamba, qui ont receu le baptesme par lesdits rr. pp. capucins. Lille, de l'imprimerie de Christofle Beys, imprimeur \& libraire, demeurant ruë de nostre Dame, au lis blanc, 1614, 31 p.

D'ABBEVILLE, Claude. Discours et congratulation a la France. Sur l'arriuée des peres capucins en l'Inde nouuelle de l'Americque meridionale en la terre du Brasil. ...: Auec la reception que leur on faict les sauuages de ce pays \& la conuersion, d'iceux à nostre saincte foy .... Declarées par six paires de lettres que deux desdits peres a sçauoir p. Claude d'Abbeuille, \& p. Arsene de Paris, predicateurs ont escrites du 20. E 27. d'aoust de l'an passé .. Paris, chez Denis Langloys, ruë Sainct Iacques pres les Iacobins., 1613. 32 p.

D'ABBEVILLE, Claude. História da Missão dos Padres Capuchinhos na Ilha do Maranhão em que se trata das singularidades admiráveis e dos costumes estranhos dos indios habitantes do país. Introdução e notas de Rodolfo Garcia. São Paulo: Livraria Martins Editora, 1945.

AMARA, Lia Arez Ferreira. Ravardière no Maranhão. In: CONGRESSO DO MUNDO PORTUGUÊS, Lisboa, v. 9, p. 238-250, 1940.

ANCHIETA, José. Diálogo da fé. Introdução histórico-literária e notas de Armando Cardoso. São Paulo: Loyola, 1988.

ANCHIETA, José. Textos históricos. Pesquisa, introdução e notas: Pe. Hélio Abranches Viotti, S.J. Obras Completas n.9. São Paulo: Edições Loyola, 1989.

ANCHIETA, José. Doutrina Cristã. Tomo 1: Catecismo brasílico. Obras completas: 10 volumes. Introdução, tradução e notas: Pe. Armando Cardoso, S.J. São Paulo: Edições Loyola, 1992a.

ANCHIETA, José. Doutrina cristã. Tomo 2: Doutrina autógrafa e confessionário. Obras Completas $10^{\circ}$ vol. Introdução histórico-literária, tradução e notas: Pe. Armando Cardoso S.J. São Paulo: Edições Loyola, 1992b.

ARAÚJO, Antônio. Catecismo Brasilico da doutrina christãa, com o ceremonial dos Sacramentos, E mais actos Parochiaes./Composto Por Padres Doutos da Companbia de Jesus, Aperfeiçoado, E dado a luz pelo Padre Antonio de Araujo da Mesma Companhia./Emendado nesta segunda impressão Pelo Bertholameu de Leam da mesma Companbia. / Lisboa./Na Officina Miguel Deslandes./MDCLXXXVI. Com todas as licenças necessarias, 1686. 
ARAÚJO, Antônio de. Catecismo na língua brasilica. (fac-símile da edição de 1618) Rio de Janeiro, Olímpica, 1952.

ARSÈNE, de Paris, père. Derniere lettre du pere Arsene de Paris. Au r.p.prouincial des capucins de la prouince de Paris. Paris?: s.n., 1612?].. Datada como "De la grande isle de Maragnan, entre les Topinanbas, ce 27. aoust, 1612. 7 p.

AYROSA, Plínio. Orações e diálogos da doutrina cristã na língua brasílica. Mss. do século XVIII, transcritos e anotados por P. Ayrosa. Boletim de Etnografia e Lingua Tupi-guarani, n.17, USP, São Paulo, 1950.

BARRE, Nicolas. Copie de quelques lettres sur la navigation du Chevalier de Villegaignon en terres de l'Amerique oultre l'oequinoctial, iusques soubz le tropique du Capricorne, contenant sommairement les fortunes encourues en ce voyage avec les moeurs et facons de vivre des sauvages du pais: envoyées par un des gens dudit seigneur. Paris, 1557 (citado por Estevao Pinto 1557).

BARROS, M.Cândida D. M. Os intérpretes jesuítas como fonte de estudo da situação lingüística colonial. In: SOARES, Marília Facó (Org.). Estudos da linguagem: limites e espaços. Mesas-redondas do VI Congresso da ASSEL - Rio. Rio de Janeiro: Associação de Estudos da Linguagem/UFRJ, p. 179-191, 1997.

BARROS, M. Cândida D.M. Esboço de uma história dos catecismos em línguas indígenas do Brasil entre os séculos XVI e XVIII. Boletim de Historiografia Brasileira, n.5, GT Anpoll, p. 53-71, 2000.

BETTENDORF, João Felipe. Compêndio da Doutrina Christãa na Lingua Portuguesa e Brasilica. Composto pelo P. João Filippe Betendorf. Antigo missionário do Brasil. e reimpresso de ordem de S. Alteza Real o Principe Regente Nosso Senhor por Fr. José Mariano da Conceição Velloso. Lisboa. MDCCC. Na officina de Simão Thaddeo Ferreira, 1800.

CARDOSO, Pe. Armando. In: ANCHIETA, José. Diálogo da fé. Obras completas - $8^{\circ}$ volume. São Paulo: Edições Loyola, 1988.

CARDOSO, Pe. Armando. In: ANCHIETA, José. Doutrina cristã. tomo I, $1992 \mathrm{a}$.

CARDOSO, Pe. Armando. In: ANCHIETA, José. Doutrina cristã. tomo II, $1992 \mathrm{~b}$.

CLASTRES, Hélène. Présentation et notes d'Hélènes Clastres. D’D'EVREUX, Yves. Voyage ao Nord du Brésil. Fait en 1613 et 1614. Paris: Payot, Bibliothèque Historique, 1985.

COMBÉS, Isabelle. La tragédie cannibale. Chez les anciens Tupi-guarani. Paris: Presses Universitaires de France, 1992.

CRULS, Gastão. Aparência do Rio de Janeiro. Notícia histórica e descritiva da cidade. Vol. I. Rio de Janeiro: José Olympio, 1949. 
DAHER, Andrea. Histoire de la mission des pères capucins au Brésil (1612-1615) In: Lestringant Frank. La France-Amérique (XVIe- XVIII siècles). Actes du XXXV colloque international d'études humanistes. Paris. Honoré Champion. 1998, p. 289-313.

DALBY, David; HAIR, P.E. H. A tupi vocabulary of 1540s. Transactions of the philological society. Oxford, 1967. p. 42-66.

DENIS, Ferdinand. Uma festa brasileira. Rio de Janeiro: Epasa, 1944.

DRUMOND, Carlos. Notas sobre algumas traduções do Padre Nosso em tupiguarani. Boletim de Etnografia e Língua Tupi-guarani. São Paulo, USP, n.14, 1948.

DURET, Claude. Thresor de l'Histoire des Langues de cest univers. Contenant les origines, beautés, perfections, decadences, mutations, changemens, conversion, y ruines des langues. par M. Claude Duret Bourbobbois, President a Moulins. Imprime a Cologny, par Matth. Berjon: 1973.

DUSSEN, Adriaen van der. Relatório sobre as capitanias conquistadas no Brasil pelos holandeses (1639). Suas condições econômicas e sociais. Instituto do Açúcar e do Álcool. Série História III. Rio de Janeiro, 1947.

ECKART, Anselm. Specimen Linguae Brasilicae vulgaris. In: MURR, Christph Gottlieb von, (Ed.): Journal zur Kunstgeschichte und zur Allgemeinen Litteratur. Nuernberg, 17, fasc. 2, 1778.

ECKART, Anselm. O Exemplário da língua corrente do Brasil de Anselm von Eckart. Trad. Carlos Antônio Kalil Tannus e Miguel Barbosa Rosário. Terceira margem. Revista da Pós-graduação em Letras da UFRJ, ano II. n.2. p. 176-180, 1994.

D'EVREUX, Ýves. Voyage dans le Nord du Brésil. Publié d'apres l'exemplaire unique conservé a la Bibliotheque Impériale de Paris. Avec une introduction et des notes par M. Ferdinand Denis. Leipzig \& Paris: Librairie A. Franck, 1864.

FARIA, Francisco Leite. Os primeiros missionários do Maranhão. Achegas para a história dos capuchinhos franceses que aí estiveram de 1612 a 1615. Centro de Estudos Históricos Ultramarinos, p. 83-216, 1961.

FAY, David Aluisio. Cartas do jesuita David Aluisio Fay. Anais da Biblioteca Nacional do Rio de Janiero, Rio de Janeiro, v. 64, 1942.

FRANCO, Afonso Arinos de Melo. O índio brasileiro e a revolução francesa. As origens brasileiras da teoria da bondade natural. 2. ed. Rio de Janeiro: José Olympio, 1976. (Coleção Documentos Brasileiros).

GARCIA, Rodolfo. Glossario das palavras e phrases da lingua tupi, contidas na Histoire de la mission des Pères capucins en l'Isle de Maragnan et Terres circovoisines do padre Claude d'Abbéville. Revista do Instituto Historico e Geographico Brasileiro, tomo 94, v. 148, 1927. 
GARRAUX, Anatole Louis. Bibliographie brésilienne. catalogue des ouvrages Français \& latins relatifs ao Brésil (1500-1898); par A.L. garraux, ex-libraire a Saint Paul (Bresil) Paris. Ch. Chadenat, 1898.

GOMEZ-GÉRAUD, Marie-Christine. Écrire le voyage au XVI siècle en France. Paris: PUF, 2000.

HISTORIA DE LA FUNDACIÓN del Collegio de la Baya de todo los Sanctos, y de sus residencias. Anais da Biblioteca Nacional, n. 19, p. 77-121, 1897.

HOLANDA, Sérgio Buarque de. Raízes do Brasil. Rio de Janeiro: José Olympio, 1978.

JORGE, Marcos. Doctrina Christã. Ordenada a maneira de Dialogos, pera ensinar os mininos, pelo Padre Marcos Jorge da Companhia de IESU, Doctor em Theologia. Acrescentada pelo Padre Ignacio Maz., da mesma Companbia, Doctor Theologo. Em Lisboa. Impresso com licença por Pedro Crasbeeck, 1602.

LACOMBE, Robert. Les conférences d'Yviret: Indiens Tabayare et Capucins de Paris (35-70). In: Guaranis et Jésuites. Un combat pour la liberté. Société d'Ethnographie.

LEITE, Serafim. História da Companbia de Jesus no Brasil. Rio de Janeiro: Instituto Nacional do Livro, 1938-50. $10 \mathrm{v}$.

LEITE, Serafim. Monumenta Brasiliae. Monumenta Historica S.I., v. 79-80-8187, Roma, 1956-60.

LERY, Jean de. Histoire d'un voyage faict en la terre du Bresil (1578). $2^{\circ}$ édition. Texte établi, présenté et annoté par Franck Lestringant. Le Livre du Poche, 1994.

LÉRY, Jean de. Histoire d'un voyage fait en la terre du Brésil / Jean de Léry; édition, présentation et notes par Jean-Claude Morisot; index des notions ethnologiques par Louis Necker. Genève: Droz, 1975.

LESTRIGANT, Franck. André Thevet, ou l'archéologie du Nouveau Monde. In: Le Huguenot et le Sawvage. L'Amerique et la controverse coloniale en France, au temps des Guerres de religion (1555-1589). Aux Amateurs de Livres, p. 39-45, 1990.

LESTRINGANT, Frank. André Thevet. Cosmographe des derniers Valois. Droz: Librairie Genève, 1991.

LESTRINGANT, Frank. La France-Amérique (XVIe-XVIIIe siècles). In: COLLOQUE INTERNATIONAL D'ÉTUDES HUMANISTES, 35, 1992, Tours, France. Actes du XXXVe colloque international d'études humanistes. Paris: H. Champion, 1998.

LESTRINGANT, Frank. Going native in America (French-style). Renaissance Studies, v. 6, n. 3-4, p. 324-335. 
LUSSAGNET, Suzanne (Org.). Les Français en Amérique pendant la deuxième moitié du XVI siècle [1]. Le Brésil et les Brésiliens. Paris: Presses Univesitaires de Frances, 1953.

MACHADO, Diogo Barbosa 1967. Bibliotbeca Lusitana, Historica, Critica, e Cronologica, na qual se comprehende a noticia dos authores portugueses, e das obras, que compozeraõ desde o tempo da promulgaçã̃ da Ley da Graça até o tempo presente; por Diogo Barbosa Machado. Lisboa. 1º edicao 1759.

MELIA, Bartomeu. La création d'un langage chrétien dans les réductions des guarani au Paraguay. 1969. Thèse (Doctorat en Sciences Religieuses) - Université de Strasbourg.

MERLIN, François. Recherche de plusieurs singularites par François Merlin controlleurs general de la maison de Seu Madame Marie Elisabeth fille unique de Seu Roy Charles dernier que Dieu absolue. Portraictes \& escrotes par Jacques Cellier demourant a Reims, 1587.

MEUNIER, Jacques. L'itinéraire d'un enfant normand (raconté aux Brésiliens). In: On dirait des îles. Flammarion, coll. Etonnants voyageurs, 1999.

MÉTRAUX, Alfred. Les indiens waitaka: à propos d'un manuscrit inédit du cosmographe André Thevet. Journal de la Société des Américanistes de Paris, t. XXI, fasc. 1. p. 107-126, 1929.

MOCQUET, Jean. Voyages en Afrique, Asie, Indes orientales et occidentales, faits par Jean Mocquet, Garde du Cabinet des Singularitez du Roi, aux Tuilleries. Divizez en six livres et enrichiz de figurez. A Paris. Chez Jean de Hevqueville, 1617.

MORENO, Diogo de Campos. Jornada do Maranhão. In: Barão de Studart. Colleção de noticias. Lisboa: Typografia da Academia Real das Ciencias, t. 1, 1812.

MUNSTER, Sebastian; BELLEFOREST, François. La Cosmographie Vniverselle de tovt le monde. En laquelle les auteurs plus dignes de foy, sont au vray descriptes toutes les parties habitables, \& non habitables de la Terre, \& de la Mer, leurs assiettes \& choses qu'elles produisent: .....Auteur en partie Munster, mais beaucoup plus augmentée, ornée \& enrichie, par François de Belleforest, Comingeois, tant de ses recherches, comme de l'aide de plusieurs memoires envoyez de diverses Villes de France, par hommes amateurs de l'histoire \& leur patrie. A Paris, Chez Nicolas Chesneau, rue S. Jaques, ao Chesne Verd, 1575.

NAVET, Eric. Le rôle des truchements dans les relations franco-amérindiennes sur la côte du Brésil au XVI siècle. In: Amerindia. 19/20, 1995.

NOGUEIRA, M.T. Alves. Villegagnon. Rio de Janeiro: Biblioteca Brasileira de Cultura/Epasa, 1944.

ORE, Luis Jeronimo. Rituale seu Manuale PeRuãoun et forma brevis administrandi apud Indos Sacrosanta Baptismi, Poenitentiae, Eucharistide, Matrimonii et Extremae Unctions. Napolis, 1607. 
PERRONE-MOISES, Leila. Vinte luas: viagem de Paulmier de Gonneville ao Brasil, 1503-1505. São Paulo: Companhia das Letras, 1992.

PEZIEU, Monsieur de. Brief recueil des particularitez contenues aux lettres enuoyeés, par Monsieur de Pezieu, a messieurs ses parents \& amis de France. De l'isle de Marignan au Brezil, où il est encores à present, pour le seruice de Sa Majesté treschrestienne Louys XIII. .. Lyon,: par Iean Poyet., M.DCXIII. [1613]. 31 p., 1615 (?) PIANZOLA, Maurice. Des Français à la conquête du Brésil XVII siècle. Les Perroquest Jaunes. Recherches \& Documents. Paris: Edition L'Harmattan, 1991.

REVERDIN, Olivier. Quatorze calvinistes chez les Topinambous. Histoire d'une mission genevoise au Brésil (1556-1558). Geneve/Paris: Droz/Minard, 1957.

ROSA, Maria Carlota. Um exemplo de descrição pedagógica no século XVIII: o Specimen linguae brasilicae vulgaris e a tradição jesuítica de ensino de segunda língua. Terceira Margem, UFRJ, n.2, p. 181-189, 1994.

SANTOS, Ilda Mendes. La découverte du Brésil. Les premiers témoignages choisis E preséntés par Ilsa Mendes dos Santos. Chandeigne, 2000.

SEMELAIGNE. Yves d'd'Evreux ou Essai de colonization au Brésil chez les Tapinambos, de 1612 a 1614. Paris: Librairie des Bibliophiles, 1887.

THEVET, Andre. Le grand insulaire, et pilotage d'André Thevet. Angoumoisin, cosmographe du Roy, dans lequel sont contenus plusieurs plants d'isles habitées, et deshabitée, et description d'icelles. Dois tomos. BN Richelieu, 1586.

THEVET, Andre. Singularidades da França Antárctica, a que outros chamam de América. Prefácio, tradução e notas de Prof. Estevão Pinto. Edição illustrada. Brasiliana. Biblioteca pedagógica brasileira. Companhia Editora Nacional, 1944.

THEVET, Andre. La Cosmographie Vniverselle d'Andre Thevet cosmographe dv Roy. Illustree de Diverses figures des chosesplus remarquables vevë par l'Auteur, E incogneuës de noz Anciens \& Modernes. A Paris Chez Pierre l'Huillier, rue S.Jacques, à l'Olivier. 1575. Avec Privilege du Roy. tomo 2, 1575.

VALENTE, José Augusto Vaz. Língua - Instrumento de colonização. Revista de História, São Paulo, p. 295-304, 1967. 


\section{ANEXO 1}

Quadro com versões do Pai Nosso (1549-1618)

\begin{tabular}{|l|l|l|}
\hline \multirow{3}{*}{1.} & Anchieta (séc.XVI) ${ }^{6}(1988: 219)$ & Oré Rúb ybákype tekoár \\
\cline { 2 - 3 } & Thevet 1586 & Ore ruue vbacpé ereico. \\
\hline Evreux [1615](1864:272) & Ore-rouue vuac peté couare. \\
\hline Araújo [1618] (1952) & Orê rûb/ Igbàcupe tecoar, \\
\hline
\end{tabular}

\begin{tabular}{|l|l|l|}
\hline 2. & Anchieta $(1988: 223)$ & Imoetepýramo nde réra toikó \\
\cline { 2 - 3 } Thevet 1586 & $\begin{array}{l}\text { Toicoap pauemgatu aua vbu } \\
\text { iagatou oquoauäe/ charäj b'- } \\
\text { amo derera reco }\end{array}$ \\
\hline Evreux [1615](1864) & \begin{tabular}{l} 
Ymoe-tepoire derere-toico \\
\hline Araújo [1618] (1952)
\end{tabular} & Ymoetè pîramo, /nde rera toicô \\
\hline
\end{tabular}

\begin{tabular}{|l|l|l|}
\hline 3. & Anchieta (1988: 224) & toú nde Reino \\
\cline { 2 - 3 } & Thevet 1586 & Oreroraso ieppé vuacpé \\
\hline Evreux [1615](1864) & to-oure de-reigne \\
\hline Araújo [1618] (1952) & Toûr nde Reino \\
\hline
\end{tabular}

\begin{tabular}{|l|l|l|}
\hline 4. & Anchieta $(1988: 225)$ & tojemoñáng nde remimotára ybýpe, \\
\cline { 2 - 3 } & Thevet 1586 & Toge mognanga deremipotare vbupé, \\
\hline Evreux [1615](1864) & Teiè-mognan deremimotare yboipé \\
\hline Araújo [1618] (1952) & Tônhémonhang/ nderemîmotaraibîpe \\
\hline
\end{tabular}

\begin{tabular}{|l|l|l|}
\hline \multirow{3}{*}{5.} & Anchieta (1988:225) & ybákype iñemoñanga jabé \\
\cline { 2 - 3 } & Thevet 1586 & vuacpé/ igemonang iaué. \\
\hline Evreux [1615](1864) & vuacpé iémognan eaue \\
\hline Araújo [1618] (1952) & Igbâcupe,ynhemonhanga yabê \\
\hline
\end{tabular}




\begin{tabular}{|l|l|l|}
\hline \multirow{6}{*}{6.} & Anchieta $(1988: 227)$ & Oré remiú ára jabiõnduára \\
\cline { 2 - 3 } & Thevet 1586 & Aräiauion ore remiou \\
\hline \multirow{2}{*}{ Evreux [1615](1864) } & Oreremiou-are aiedouare \\
\hline Araújo [1618] (1952) & Orê remiu/ Ara yabiõ ndoâra \\
\hline
\end{tabular}

\begin{tabular}{|l|l|l|}
\hline 7. & Anchieta $(1988: 227)$ & eimeéng korí orébo \\
\cline { 2 - 3 } & Thevet 1586 & ëimëong cori oréue. \\
\hline Evreux [1615](1864) & eimé ioury oreue \\
\hline Araújo [1618](1952) & Eimeeng cori orebe. \\
\hline
\end{tabular}

\begin{tabular}{|l|l|l|}
\hline \multirow{3}{*}{8.} & Anchieta (1988: 229) & nde ñyrõ, Tupa \\
\cline { 2 - 3 } & Thevet 1586 & $\begin{array}{l}\text { De guron oréuo orememoan } \\
\text { angäi peue supé, }\end{array}$ \\
\cline { 2 - 3 } & Evreux [1615](1864) & De-ieurou orè yangaypaue ressé \\
\hline Araújo [1618](1952) & Nde nhirõ/ Ore angaipaba recè/ Orebe \\
\hline
\end{tabular}

\begin{tabular}{|l|l|l|}
\hline \multirow{2}{*}{9.} & Anchieta $(1988: 230)$ & oré rerekómemuãsára supé \\
\cline { 2 - 3 } & Thevet 1586 & orerecomemoasara supé \\
\hline Evreux [1615](1864) & ore recome-mossaré soupé \\
\hline Araújo [1618] (1952) & ore terecõmemoáçara çupe \\
\hline
\end{tabular}

\begin{tabular}{|l|l|l|}
\hline \multirow{2}{*}{10.} & Anchieta $(1988: 230)$ & oré ñyrõ jabé, nde ñyrõ orébe \\
\cline { 2 - 3 } & Thevet 1586 & oregiron iäué. \\
\hline Evreux [1615](1864) & ore-ieuron eaue \\
\hline Araújo [1618](1952) & Ore nhirõ yabe \\
\hline
\end{tabular}

\begin{tabular}{|l|l|l|}
\hline 11. & Anchieta (1988: 230) & Ore moárukár umé jepé \\
\cline { 2 - 3 } Thevet 1586 & $\begin{array}{l}\text { Eipotarumé aignang oremémoaugé. } \\
\text { Eipea pauemgne } \\
\text { ba ememoam oré suy }\end{array}$ \\
\hline Evreux [1615](1864) & Moar-ocar humé yepé \\
\hline Araújo [1618](1952) & Ore moarû carumé yepe \\
\hline
\end{tabular}




\begin{tabular}{|l|l|l|}
\hline \multirow{2}{*}{12.} & Anchieta $(1988: 230 / 233)$ & tentação pupé/ ore pysyrõ té jepé \\
\cline { 2 - 3 } & Thevet 1586 & $\begin{array}{l}\text { tecomemo-poupé/ ore pessuron } \\
\text { peyepè }\end{array}$ \\
\hline Evreux [1615](1864) & \begin{tabular}{l} 
tentação pupé:/ore pi cirõte yepe, \\
\hline Araújo [1618](1952)
\end{tabular} \\
\hline
\end{tabular}

\begin{tabular}{|l|l|l|}
\hline \multirow{3}{*}{13.} & Anchieta (1988:233) & mbaéaíba suí \\
\cline { 2 - 3 } & Thevet 1586 & \\
\hline Evreux [1615](1864) & mäe ayue souy \\
\hline Araújo [1618](1952) & Mbaê aiba çui. \\
\hline
\end{tabular}

\begin{tabular}{|l|l|l|}
\hline 14. & Anchieta $(1988: 234)$ & Amém \\
\cline { 2 - 3 } & Thevet 1586 & Emona né toico, Jesus \\
\hline Evreux [1615](1864) & Amen Iesu \\
\hline Araújo [1618](1952) & Amen IESU \\
\hline
\end{tabular}




\section{ANEXO 2}

Orações em tupi na obra Le grand insulaire de André Thevet (1586)

\section{Oraison Dominicale du Sauvage [ 252 ]}

Toupan [a palavra está cortada]

Ore ruue vbacpé ereico.

Toicoap pauemgatu aua vbu iagatou oquoauäe

charäj b'-amo derera reco

Oreroraso ieppé vuacpé.

Toge mognanga deremipotare vbupé, vuacpé

igemonang iaué.

Aräiauion ore remiou ëimëeng cori oréue. [253]

De guron oréuo orememoan angäi peue supé,

orerecomemoasara supé oregiron iäué.

Eipotarumé aignang orememoaugé.

Eipea pauemgne ba ememoan oré suy.

Emona né toico, Jesus.

\section{Salutation Angelique}

De Rory Maria toupan oico de irumnamo de agnonnian ereico imombeou gatoupiramo cogna suy aë aué de suy osenuaë puera Jesus.

Santa Maria toupan su eieruré demembouira supé tigburon oréue, ore memoan angäi paua supé.

Emona né toico Jesus.

\section{Le Simbole des Apostres}

Arobia toupan rouua mäe tetiroan supé yhauanga uemaë ubacque mognangare, uboy aue mognangare.

Arobia Jesu $\mathrm{X}^{2}$ taüre ojeppé, toupan espirito Santos,

1 THEVET, André. 1586. Le grand insulaire et pilotage d'André Thevet. Angoumoisin, Cosmographe du Roy. Dans lequel sont contenus plusieurs plants d'isles habitées, et deshabitées, et description d'icelles. Dois tomos. Bibliothèque Nationale. Richelieu: Ms. fr. 15452./f.207 verso à 413/Microfilm R120377. Transcrição de Maria Cândida D.M. Barros.

${ }^{2}$ Símbolo gráfico para Cristo. 
o Joese, Igemosae nandape turi yan eroo rauo aëosen Maria Vurgon suy, baërasy catupaue Pilato oiporarauoap ysupe ubuira gecunasaue ry ymoiamaruca seon rire, Ita caramemoam pupé ytuma yanga oso ognanga retam, aësuytury ouo oraue, opoërape carai caturamo oïconoë mosapöi arapoupe ygeou poiri ubacpé teonbouere reid suy ouapicqua o Juona, Ecatouuaua, cotyoïne mäetetiroan supé yhauam gabmäe aësuyturime oïcoueuaë, omanoueuäe, puera, recopuera repu eenge ysupene: Arobia Espirito Santos, Arobia toupan rocqu gemonya raïpaue toupan rosé ogerobia ruuae gemongaraïpaue: Arobia ychegnuam pupé catou toupan rorupape ycaraïcatouäe gognuignangaue à Seraroaue soupé gurundaua à serete poërapaue, Arobia toupan rorypane à sereco be boucon.

Emona né toico Jesus. 


\section{ANEXO 3}

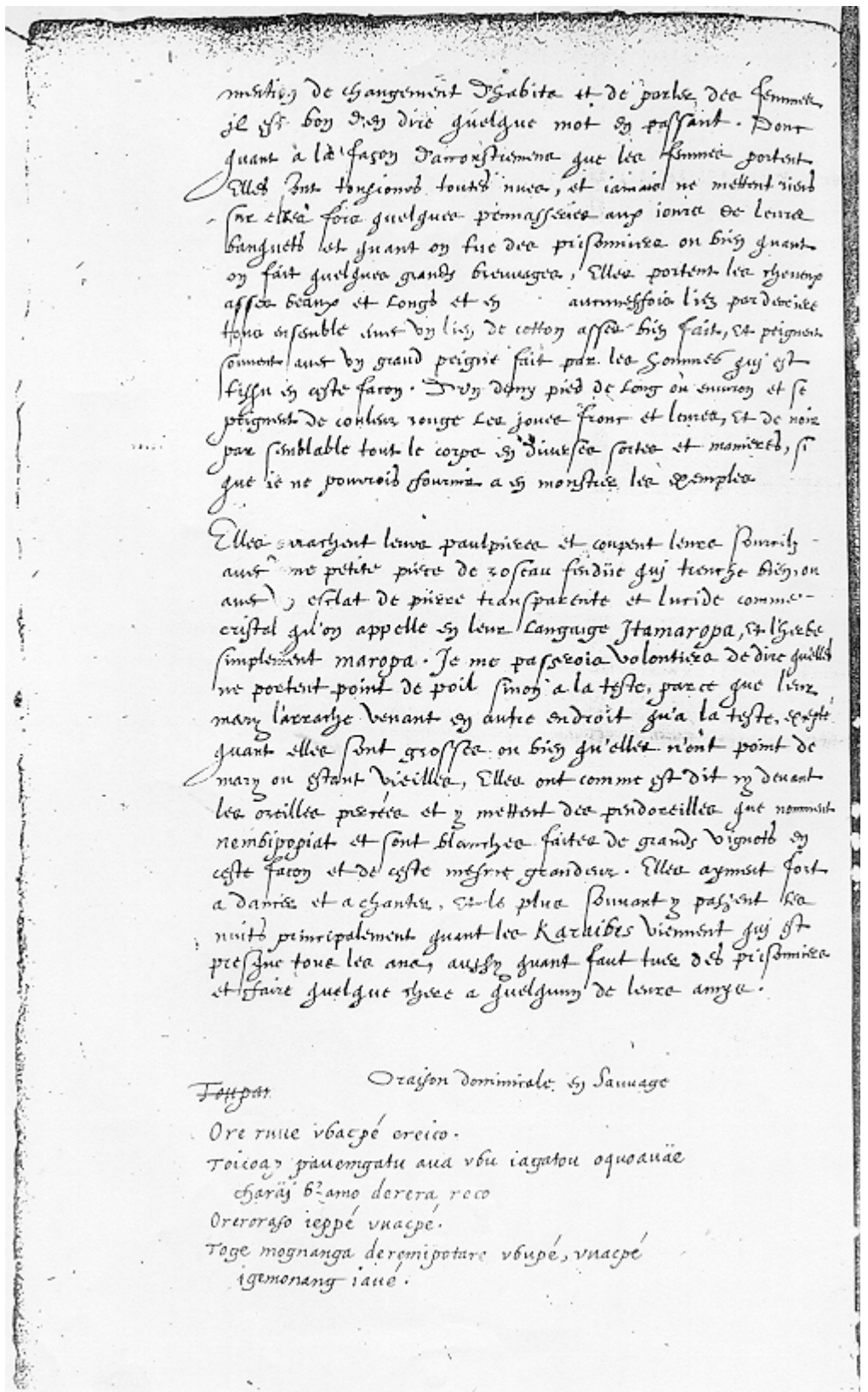




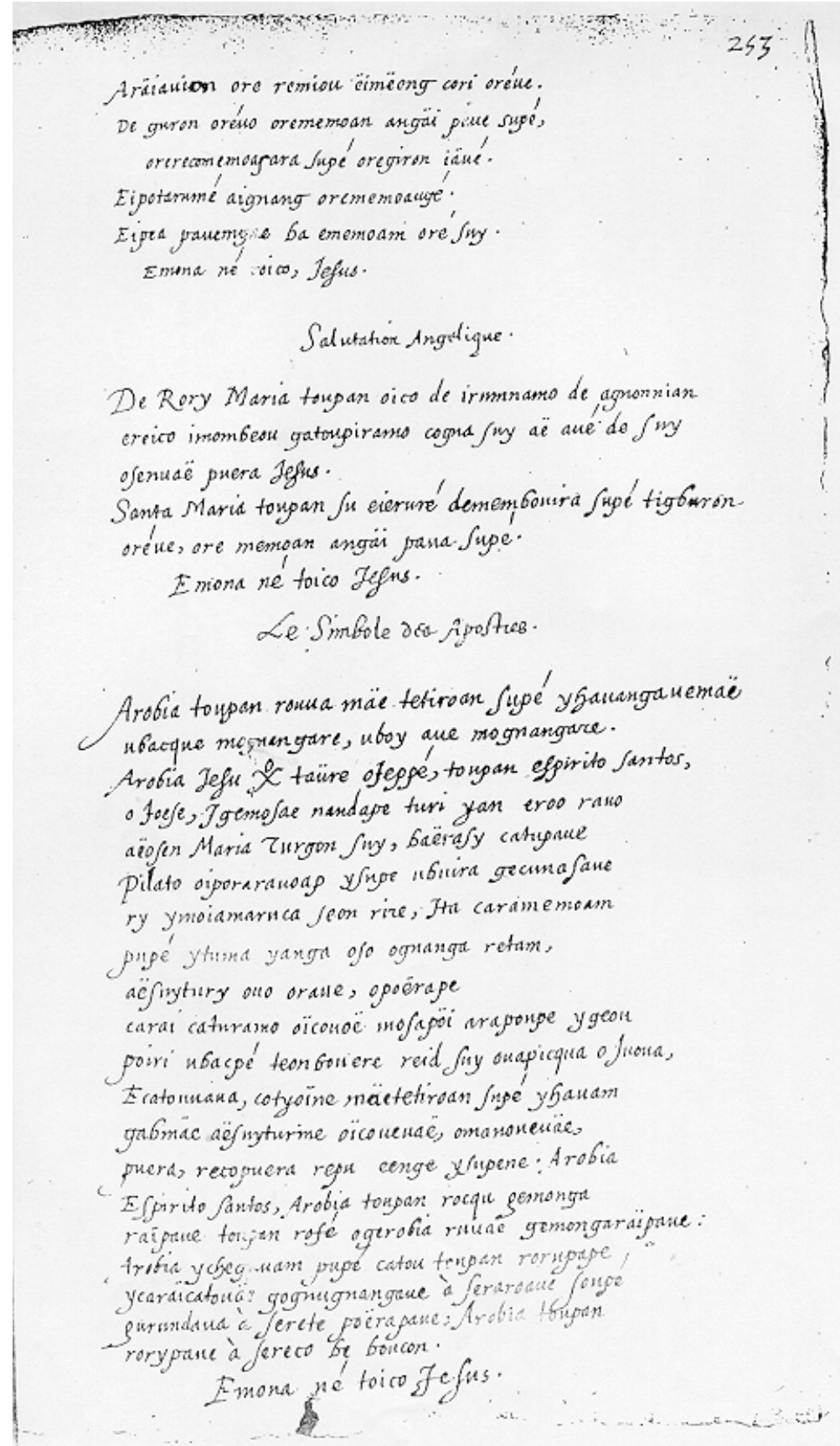


Rev. Est. Ling., Belo Horizonte, v.10, n.1, p.139-187, jan./jun. 2002

\section{ANEXO 4}

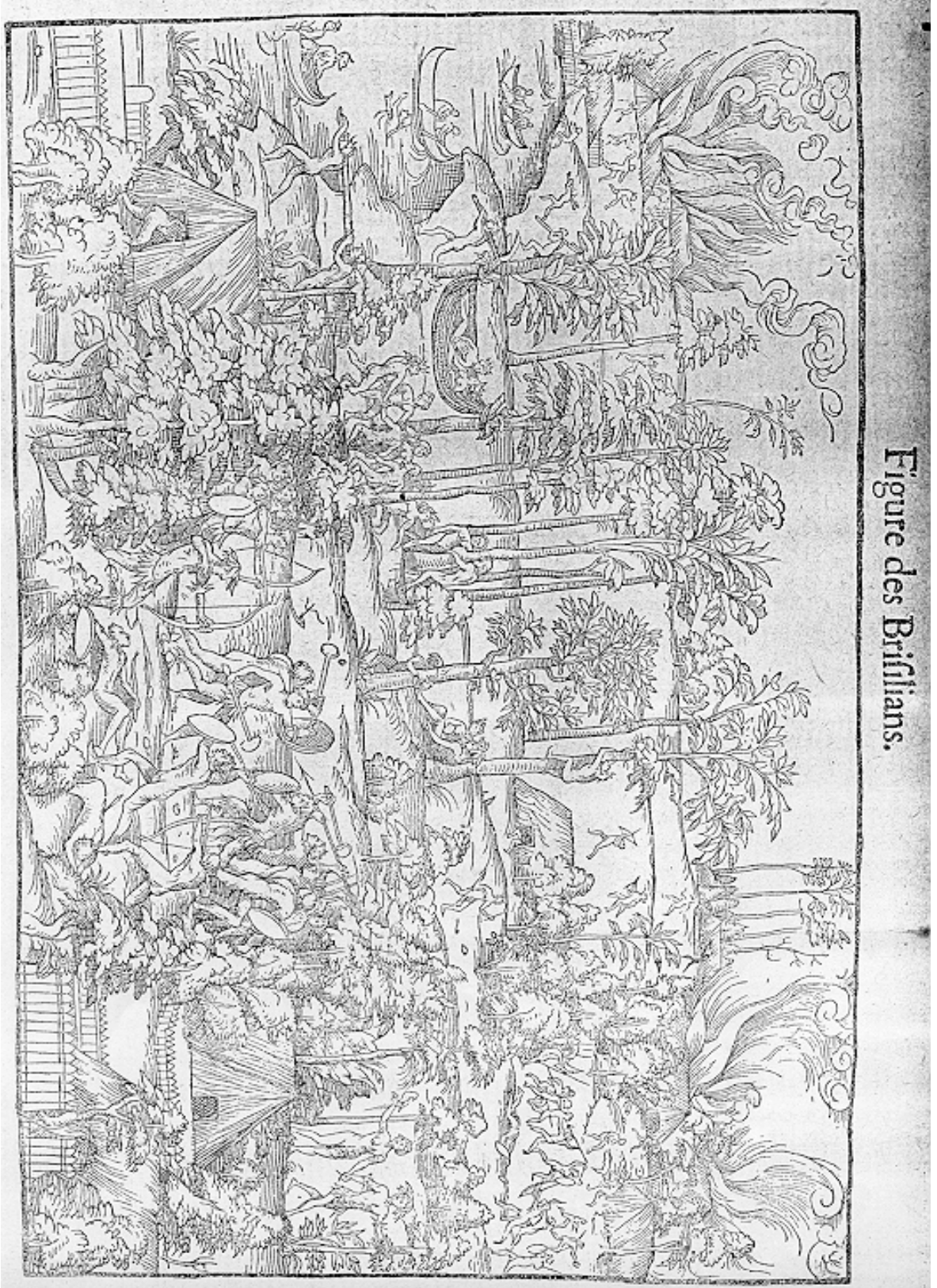

DENIS, Ferdinad. Uma festa brasileira. Rio de Janeiro: Epasa. 1944. 